\title{
The regional impact of urban emissions on climate over central Europe: present and future emission perspectives
}

\author{
Peter Huszár, Michal Belda, Jan Karlický, Petr Pišoft, and Tomáš Halenka \\ Department of Atmospheric Physics, Faculty of Mathematics and Physics, Charles University, Prague, V Holešovičkách 2, \\ 18000 Prague 8, Czech Republic
}

Correspondence to: Peter Huszár (peter.huszar@mff.cuni.cz)

Received: 18 May 2016 - Published in Atmos. Chem. Phys. Discuss.: 27 June 2016

Revised: 24 August 2016 - Accepted: 1 October 2016 - Published: 21 October 2016

\begin{abstract}
The regional climate model RegCM4.2 was coupled to the chemistry transport model CAMx, including twoway interactions, to evaluate the regional impact of urban emission from central European cities on climate for presentday (2001-2010) and future (2046-2055) periods, and for the future one only emission changes are considered. Short-lived non- $\mathrm{CO}_{2}$ emissions are considered and, for the future impact, only the emission changes are accounted for (the climate is kept "fixed"). The urban impact on climate is calculated with the annihilation approach in which two experiments are performed: one with all emissions included and one without urban emissions. The radiative impacts of non- $\mathrm{CO}_{2}$ primary and secondary formed pollutants are considered, namely ozone $\left(\mathrm{O}_{3}\right)$, sulfates $\left(\mathrm{PSO}_{4}\right)$, nitrates $\left(\mathrm{PNO}_{3}\right)$, primary organic aerosol and primary elementary carbon (POA and PEC).

The validation of the modelling system is limited to key climate parameters, near-surface temperature and precipitation. It shows that the model, in general, underestimates temperature and overestimates precipitation. We attribute this behaviour to an excess of cloudiness/water vapour present in the model atmosphere as a consequence of overpredicted evaporation from the surface.

The impact on climate is characterised by statistically significant cooling of up to -0.02 and $-0.04 \mathrm{~K}$ in winter (DJF) and summer (JJA), mainly over cities. We found that the main contributors to the cooling are the direct and indirect effects of the aerosols, while the ozone titration, calculated especially for DJF, plays rather a minor role. In accordance with the vertical extent of the urban-emission-induced aerosol perturbation, cooling dominates the first few model layers up to about $150 \mathrm{~m}$ in DJF and $1000 \mathrm{~m}$ in JJA. We found a clear
\end{abstract}

diurnal cycle of the radiative impacts with maximum cooling just after noon (JJA) or later in afternoon (DJF). Furthermore, statistically significant decreases of surface radiation are modelled in accordance with the temperature decrease. The impact on the boundary layer height is small but statistically significant and decreases by 1 and $6 \mathrm{~m}$ in DJF and JJA respectively. We did not find any statistically significant impact on precipitation and wind speed. Regarding future emissions, the impacts are, in general, smaller as a consequence of smaller emissions, resulting in smaller urban-induced chemical perturbations.

In overall, the study suggest that the non- $\mathrm{CO}_{2}$ emissions play rather a minor role in modulating regional climate over central Europe. Much more important is the direct climate impact of urban surfaces via the urban canopy meteorological effects as we showed earlier.

\section{Introduction}

High population densities in urban areas, as well as concentrated human activities, result in an intense emission source. The United Nations reports the year 2009 as the first with more the $50 \%$ of the Earth's population living in cities (UN, 2009). Therefore, an understanding of their impact on the environment, both within the city itself and on larger scales outside of it, is gaining huge importance.

Among the many types of urban impact on environment, Folberth et al. (2015) defines the impact on the atmospheric environment as the "most important and most far-reaching". Cities influence both the meteorology and atmospheric chemistry in many ways: (i) urban areas are 
largely covered by artificial surfaces, being clearly distinguished from natural ones by mechanical, radiative, thermal and hydraulic properties. These surfaces affects the mechanical and thermodynamical properties of the air atmosphere above in a very specific way (Lee et al., 2011; Huszar et al., 2014); (ii) cities emit large amounts of gaseous material and aerosol into the air, directly influencing air quality and atmospheric chemistry in general (Timothy and Lawrence, 2009; Huszar et al., 2016); (iii) direct emissions of greenhouse gases (GHGs) and aerosol and the urban-emissioninduced perturbation of secondary formed radiatively active gases and aerosols lead to modification of radiative and thermal balance, cloud properties and climate (Seinfeld and Pandis, 1998; Folberth et al., 2015).

The complex nature of the influence of the urban canopy on meteorological conditions and climate has been identified since the early 1980 s along with the description of the urban heat island effect (UHI; Oke, 1982). Since then, many studies examined UHI and related urban impacts on meteorology, e.g. on temperature (Basara et al., 2008; Gaffin et al., 2008), humidity (Richards, 2004), turbulence (Roth, 2000; Kastner-Klein et al., 2001), the overall structure of the boundary layer (Angevine et al., 2003), wind speed (Hou et al., 2013), precipitation and the hydrological cycle (Rozoff et al., 2003). With the introduction of simple-to-complex urban canopy parameterisations/models, modelling approaches to urban effects on meteorology became widespread, examining local (Flagg and Taylor, 2011; Wouters et al., 2013; Hou et al., 2013) and regional scales as well (Feng et al., 2013; Trusilova et al., 2008; Struzewska and Kaminski, 2012; Huszar et al., 2014). The listed studies (and many more, see references within) show that the impact of cities on meteorology and climate is usually not limited to the geographical location of the city itself, but propagates to regional scales and that urbanisation can contribute to regional warming (e.g. Huszar et al., 2014).

Regarding the second pathway (ii), urban emissions impact the composition of the air and chemistry, in general, on every scale from local to global, depending on the location of the city and on the lifetime of the emitted or secondaryproduced pollutants (Baklanov et al., 2010; Folberth et al., 2015). Long-lived species emitted by large cities like carbon dioxide $\left(\mathrm{CO}_{2}\right)$ affect the chemical composition over the entire globe (e.g. Lawrence et al., 2007; Folberth et al., 2012) while the urban impact concerning short-lived pollutants like nitrogen oxides $\left(\mathrm{NO}_{x}\right)$, ozone $\left(\mathrm{O}_{3}\right)$ is more limited to local and regional scales (Im and Kanakidou, 2012; Im et al., 2011a, b; Huszar et al., 2016).

There are a large number of studies that focused on the impact of short-lived pollutants from cities on local, regional and even global scales. Measurement-based studies investigated the differences between the urban plume and the background environment composition (e.g. Freney et al., 2014; Molina et al., 2010; Kuhn et al., 2010). There have also been model-based efforts to estimate the fingerprints of cities on the atmospheric chemistry across multiple scales. On the global scale, Lawrence et al. (2007), Butler and Lawrence (2009), Folberth et al. (2010), Butler et al. (2012) and Stock et al. (2013) gave estimates of the emission impacts on the environment. On regional scales, many studies focused on European urban centres (e.g. Hodnebrog et al., 2011; Im and Kanakidou, 2012; Finardi et al., 2014; Skyllakou et al., 2014; Markakis et al., 2015; Markaris et al., 2016), on megacities in eastern Asia (Guttikunda et al., 2003; Tie et al., 2013) and Mexico city (Li et al., 2011).

Much less work has been done regarding the climate impact of urban emissions and consequent chemical perturbations (pathway iii). Recently, two reviews by Folberth et al. (2015) and Baklanov et al. (2016) were published addressing the urban emission impact on climate (among other impacts). Focusing on so-called megacities (inhabitants larger than 10 million), both agree that there is high confidence of the climate impact of emitted $\mathrm{CO}_{2}$ and that much of the radiative impact of urban emission is attributable to this gas. Folberth et al. (2012) estimate the global radiative forcing (RF) emitted by megacities to $120.0,28.4$ and $3.3 \mathrm{~mW} \mathrm{~m}^{-2}$ from the long-lived components $\mathrm{CO}_{2}$, methane $\left(\mathrm{CH}_{4}\right)$ and nitrous oxide $\left(\mathrm{N}_{2} \mathrm{O}\right)$ respectively. For the impact of shortlived species, namely ozone and aerosol, they give a global mean RF $5.7 \pm 0.02 \mathrm{~mW} \mathrm{~m}^{-2}$ due to the increase in tropospheric ozone and $-6.1 \pm 0.21 \mathrm{~mW} \mathrm{~m}^{-2}$ due to urbaninduced aerosol increase. Comparing these last two numbers, it is clear that on a global average, the effects of ozone and aerosol climate nearly cancel each other out.

On local and regional scales, however, the impact of short-lived pollutants can be substantially more important (Baklanov et al., 2016). As a result of $\mathrm{NO}_{x}$ and nonmethane volatile organic compound (NMVOC) emissions, ozone forms and under favourable weather conditions it can accumulate over and around cities. Consequently, it can trigger positive radiative forcing that results in local/regional warming (Park et al., 2001). Many studies showed significant effects of aerosol originating from cities or highly populated agglomerations on radiation, consequently affecting meteorology and climate. Black carbon from an Indian megacity was investigated by Tripathi et al. (2005). Giorgi et al. (2002) attributed observed cooling in a highly populated area in China to sulfate and carbonaceous aerosol originating from the same area. Ramanachan and Kedia (2010) looked at black carbon pollution over Ahmedabad, India and indicated its important role in the radiative budget, possibly affecting monsoon rainfall. Roldin et al. (2011) calculated the radiative impact of aging urban plumes from Malmö, Sweden and found a RF from -0.3 to $-3.3 \mathrm{~mW} \mathrm{~m}^{-2}$ depending on the distance from the city and the specific cloud properties.

As already said, the globally averaged impact of shortlived gases/aerosols is of rather minor importance. However, previously listed studies prove that their effect can be significant locally; therefore it is important to examine the distribution of the climate impact of urban emission on smaller 
scales as well. Furthermore, these studies calculated the individual impacts of selected pollutants but, given the non-linear nature of the impact of emissions on climate, the overall impact may somewhat differ from that one calculated as the sum of individual impacts from ozone and aerosols. Many studies looked at the chemical perturbations introduced by urban emissions, as already listed before. However, none of them were interested in the radiative impacts of these perturbations or, more specifically, how the ozone (which can include both decreases and increases) and aerosol concentration changes affect the radiative balance and consequently the climate. We introduce this study as one of the first that quantifies the climate impact of urban emission on a regional scale. We use an interactively coupled regional climate-chemistry modelling framework. Indeed, given the strong ties between emission, air chemistry and radiative impacts, an integrated approach is required. Our region of focus is central Europe, looking at medium-sized cities often exceeding 1 million inhabitants. The paper is a follow-up study to Huszar et al. (2016), in which we were interested in the air-quality changes induced by urban emissions. In this study, as a further step in analysing the results, we investigate the consequences for climate. Besides the present-day urban impact, we will also examine how this changes using future emissions of short-lived (non- $\mathrm{CO}_{2}$ ) pollutants.

\section{Models and experimental design}

\subsection{Models}

Models and their configurations are identical to those in Huszar et al. (2016), which may be referred to for more detailed insight. Here we only give a rather brief description. As a meteorological driver, regional climate model RegCM4.2 was applied (Giorgi et al., 2012) with the following parameterisations: surface processes - BATS scheme Dickinson et al. (1993), large-scale precipitation - SUBBEX (Pal et al., 2000), convection - Grell scheme (Grell, 1993), planetary boundary layer - Holtslag scheme (Holtslag et al., 1990). The radiative transfer is calculated with the NCAR Community Climate Model Version 3 (CCM3; Kiehl et al., 1996). This scheme describes the effect of different GHGs, cloud water and cloud ice. Cloud radiative properties are calculated according to cloud liquid water content and effective droplet radius, while the fraction of cloud ice is diagnosed as a function of temperature. The radiative properties of sulfate aerosol are calculated according to Kiehl et al. (2000). For carbonaceous aerosols, optical properties were extracted from the biomass-burning study of Reid et al. (2005). By default, climatological zonally averaged ozone profiles are prescribed in RegCM after Dütsch (1978). We further did not consider urban-canopy-related meteorological effects (as interested purely on the effect of emissions), i.e. the SLUCM urban model implemented under BATS (Huszar et al., 2014) was not invoked.
The model RegCM4.2 has been coupled online to the chemistry transport model (CTM) CAMx. CAMx is an Eulerian photochemical CTM developed by ENVIRON Int. Corp. (http://www.camx.com). CAMx includes multiple gas phase chemistry mechanism options (CB-IV, CBV, CBVI, SAPRC99). In this study, the CBV scheme (Yarwood et al., 2005) was used. CAMx further implements multi-sectional or static two-mode particle size treatments, wet deposition of gases and particles, plume-in-grid (PiG) module for subgrid treatment of selected point sources, ozone and particulate source apportionment technology, mass conservative and consistent transport numerics as well as parallel processing. To calculate the composition and phase state of the ammonia-sulfate-nitrate-chloride-sodium-water inorganic aerosol system in equilibrium with gas phase precursors, the ISORROPIA thermodynamic equilibrium model (Nenes and Pandis, 1998) is implemented.

The two models are coupled using the technique of online access coupling defined by Baklanov (2010). Data between models are exchanged on a hourly basis: RegCM4.2 was run for $1 \mathrm{~h}$ after CAMx was driven with the output of the RegCM4.2 run. The calculated chemical concentrations are supplied back to the RegCM4.2's radiation code. The whole cycle is then repeated. According to Grell and Baklanov (2011), this is a justifiable update time for the resolution used. The species provided by CAMx to RegCM4.2 and considered in radiation calculations in $\mathrm{CCM} 3$ are ozone, secondary inorganic aerosols, including sulfates $\left(\mathrm{PSO}_{4}\right)$ and nitrates $\left(\mathrm{PNO}_{3}\right)$, and primary organic and inorganic carbon (OC and $\mathrm{BC}$ ). In the used climate model, the radiative effects of only $\mathrm{PSO}_{4}, \mathrm{BC}$ and $\mathrm{OC}$ are included, while for nitrates we slightly modified the sulfate optical properties following McMeeking et al. (2005). Furthermore, to include the indirect effects of secondary inorganic aerosols, we implemented the work by Giorgi et al. (2002). They considered only sulfates; however, we used their approach for nitrates as well with a slight modification following Wang et al. (2010). We denote this coupled system RegCMCAMx4 and it is basically an advanced version of the original RegCMCAMx introduced by Huszar et al. (2012). In further text, the term "model" will always refer to the RegCMCAMx4 coupled modelling system.

\subsection{Experimental set-up}

The model was run at $10 \mathrm{~km} \times 10 \mathrm{~km}$ horizontal resolution centred over Prague, Czech Republic with $160 \times 120 \times 24$ (in $x, y$ and $z$ direction) grid boxes. The uppermost level for the climate is at $50 \mathrm{hPa}$, while the chemistry was integrated only on the lowermost 16 levels (approximately up to $300 \mathrm{hPa}$ ). Numerous experiments were carried out for the period 2001-2010 and a future period, 2046-2055. As meteorological initial and boundary conditions (ICBC) we used the ERA-Interim reanalysis (Simmons et al., 2010). For chemical ICBC, we performed a larger $30 \mathrm{~km} \times 30 \mathrm{~km}$ domain run 
covering the whole of Europe. This choice was motivated by acquiring better ICBC for chemistry when the chemical processes are developed on a much larger domain. This large domain run was driven by time-space invariant chemical ICBC, which resulted in some model biases detailed by Huszar et al. (2016), especially regarding ozone. Biogenic emission of isoprene and monoterpenes were computed online according to Guenther et al. (1993).

As we were interested in how the urban impact will change in future due to modified emissions only, we used the same meteorological (ERA-Interim) and chemical initial and boundary conditions for the future period as for the present-day period. Only the anthropogenic emissions used were different (see below). This choice was further based on the assumption that the mainly long-lived GHG-driven climate change will not cause significant differences in climate between the years 2046-2055 and 2001-2010 and that the added change triggered by urban emissions will depend mostly on the emissions and not on the background climate.

\subsection{Emissions}

The TNO emissions prepared in the framework of the FP 7 MEGAPOLI project (Kuenen et al., 2010) were used in this study. This high-resolution $\left(1 / 8^{\circ}\right.$ longitude $\times 1 / 16^{\circ}$ latitude, roughly $7 \mathrm{~km} \times 7 \mathrm{~km}$ ) European emission database provides annual emissions estimates for $\mathrm{NO}_{x}$, sulfur dioxide $\left(\mathrm{SO}_{2}\right)$, NMVOC, $\mathrm{CH}_{4}$, ammonia $\left(\mathrm{NH}_{3}\right)$, carbon monoxide $(\mathrm{CO})$ and $\mathrm{PM}_{10}$ and $\mathrm{PM}_{2.5}$ in 10 activity sectors. Additionally, future sector- and country-based scaling factors are introduced for the reference years 2020, 2030 and 2050. For the energy sectors, the scenarios have been generated based on energy model runs using the pan-European TIMES energy system model (Blesl et al., 2010). A moderate climate policy is assumed, which gives the option of applying further mitigation strategies. In case of non-energy related sectors, scaling factors were calculated with the GAINS model (Amann et al., 2008) or other assumptions. A detailed description of the procedure and how emission factors and future scaling factors were extracted is provided by Theloke et al. (2010).

TNO annual emission data were regridded into the model grid. After, sector-specific temporal disaggregation factors and NMVOC speciation profiles were applied to decompose the annual sums into hourly emissions according to Winiwarter and Zueger (1996). Figure 1 presents the annual emission interpolated to our grid for gaseous pollutants and $\mathrm{PM}_{2.5}$ for the base year, 2005, and the difference between 2050 and 2005. It clearly indicates emission reductions for every species. However, due to increased energy demand in future, some sectors such as sector 2 (small and medium combustion plants), sector 3 (industrial combustion plants as well as sector) 7.3 (LPG road transportation) or sector 8 (non-road transport including airport traffic) and mobile machinery will produce more emissions. This is clear from $\mathrm{NMVOC}, \mathrm{NO}_{x}$,
$\mathrm{PM}_{2.5}$ as well as $\mathrm{SO}_{2}$, especially for south-eastern countries in Europe.

The question is how would the findings change if mitigation strategies in moderate climate policy fail or do not achieve the emission target. Here, we can simply assume that in this case the future (urban) emissions would remain at the current level and their impact in the future would be similar to the present-day.

\subsection{Experiments}

Several experiments were performed for the two periods (2001-2010 and 2046-2055), i.e. around the reference emission years 2005 and 2050. Adopting the annihilation approach (Baklanov et al., 2016), a run with all emission was first carried out for each period, denoted 05BASE and 50BASE (referring to the last two digits of the emission years). Afterwards, by removing urban emission for large cities (we used the threshold 500000 inhabitants for western Europe and 100000 for eastern Europe; for more details see Huszar et al., 2016), "zero" experiments were performed for 05ZERO and 50ZERO.

In order to identify the climate signal of urban-emissioninduced perturbations, one has to account for the effect of the variability of the modelled climate. This can be achieved by performing ensembles of a few members for all experiments. The goal is to separate the signal information from the noise. However, there is no a priori knowledge of how many members are required so we decided, on the basis of our computer and time resources, to run ensembles with three members, similarly to Olivie et al. (2012) and Huszar et al. (2013), who looked at transport emission impacts on climate. We have chosen the ensemble mode rather than adopting the scaling approach which is based on the assumption that the forcing (emission in this case) and signal are linearly connected. The perturbed experiments (2-2 for the ZERO and BASE experiments) were achieved by running the model with a reduced time step for the first few days of the simulated decades. This ensured that the ensemble members were physically equivalent and the only difference was noise coming from the internal model variability.

The climate is usually defined as the average weather (including extremes) over 30 years. We only selected a 10 -yearlong period which represents the current conditions in our study. It has to be justified that this decade is characteristic of a longer period (i.e. it is not too warm or extraordinarily cold). Furthermore, for the future period, only emission changes are considered, so we are also interested in the possible modification of the climate over the region in focus. Figure 2 shows the 1970-2050 annual and 10-year running mean of near-surface temperature averaged over our domain calculated from the EURO CORDEX regional climate models ensemble consisting of 25 members (RCM-GCM combinations) following the RCP 4.5 scenario (Jacob et al., 2013; Kotlarski et al., 2014). According to this figure, the 2001- 

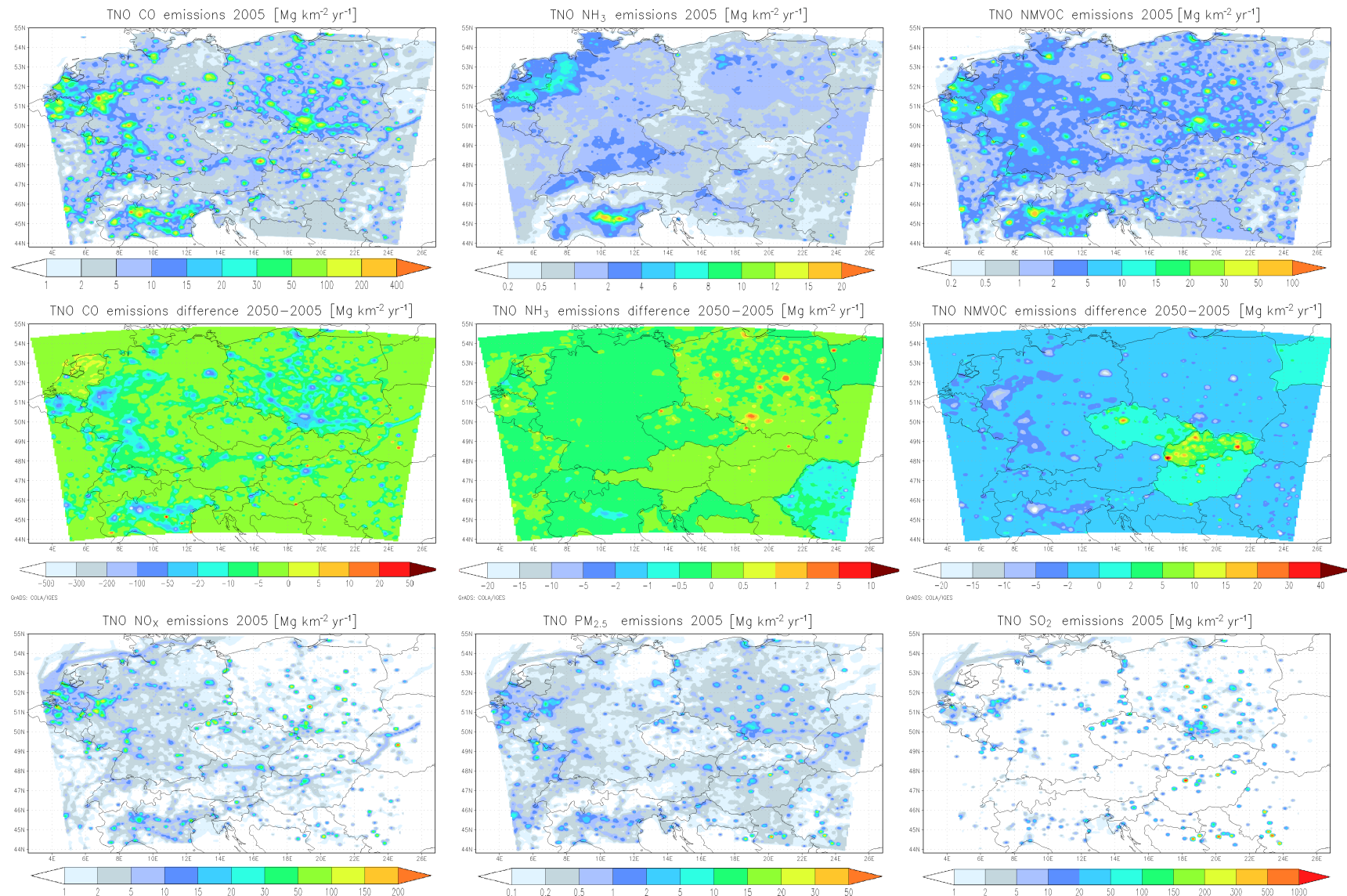

TNO NOX emissions difference $2050-2005\left[\mathrm{Mg} \mathrm{km}^{-2} \mathrm{yr}^{-1}\right]$
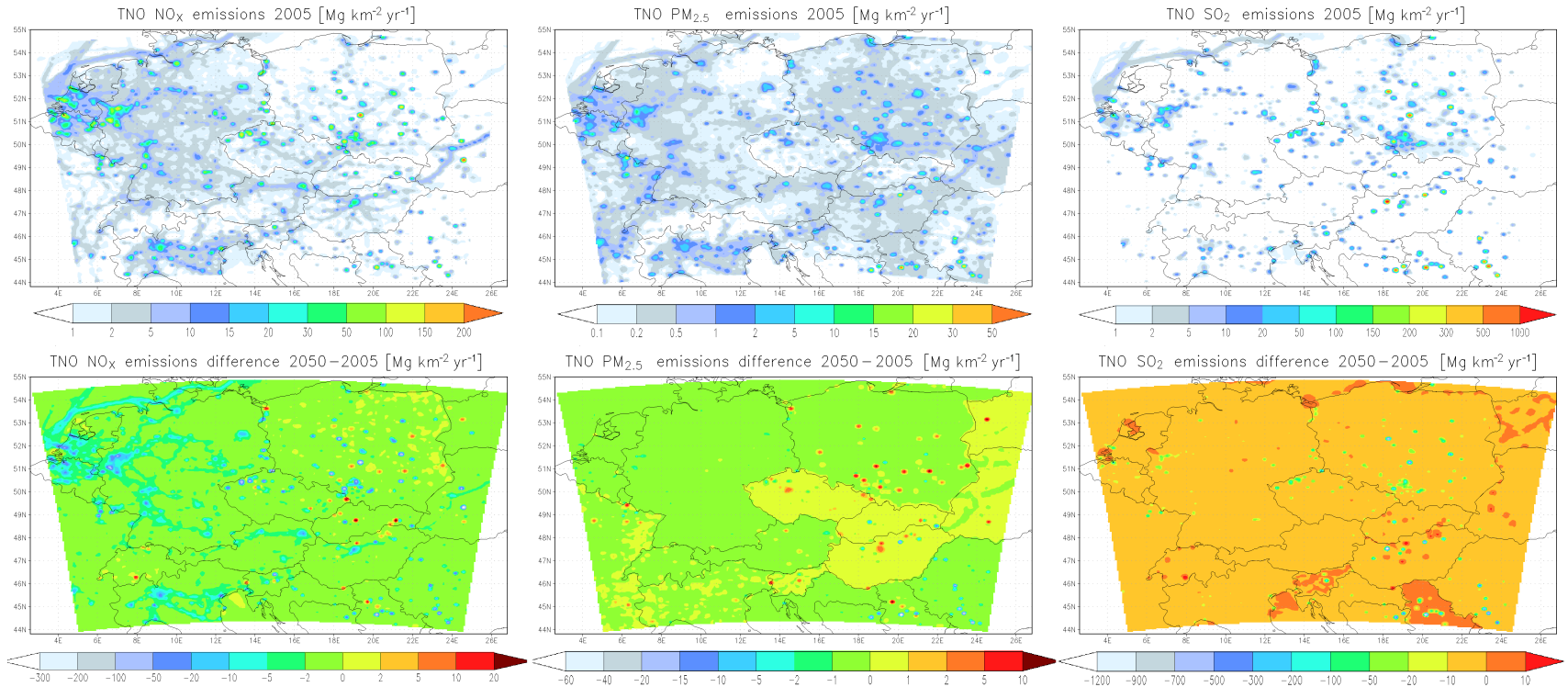

Figure 1. Base year (2005) annual emissions (rows 1 and 3) and the projected change between the years 2050 and 2005 (rows 2 and 4) for $\mathrm{CO}, \mathrm{NH}_{3}, \mathrm{NMVOC}, \mathrm{NO}_{x}, \mathrm{PM}_{2.5}$ and $\mathrm{SO}_{2}$ in $\mathrm{Mg} \mathrm{yr}^{-1} \mathrm{~km}^{-2}$.

2010 average temperature (about $8.5^{\circ} \mathrm{C}$ ) is characteristic or typical of the respective longer 30 -year time period. Furthermore, the increase of temperature for the 2046-2055 period is about $1{ }^{\circ} \mathrm{C}$. A similar temperature increase was modelled for a very similar domain (and at the same resolution) in Juda-Rezler et al. (2012) for the 2040-2050 period. They investigated the impact of future climate change on air quality and found that for this period the impact is insignificant.

\section{Results}

\subsection{Model validation}

A detailed validation of the chemical results of the presented experiments was performed in Huszar et al. (2016). The main shortcomings of the model were (1) negative ozone bias and underestimated daily cycle caused mainly by the imposed time-invariant lateral boundary conditions; (2) a general underestimation of nitrogen dioxide $\left(\mathrm{NO}_{2}\right)$ due to suppressed NO-to- $\mathrm{NO}_{2}$ conversion; (3) overestimation of sulfur dioxide $\left(\mathrm{SO}_{2}\right)$ in DJF and the opposite in JJA, caused mainly through incorrect monthly disaggregation of the annual emission to- 


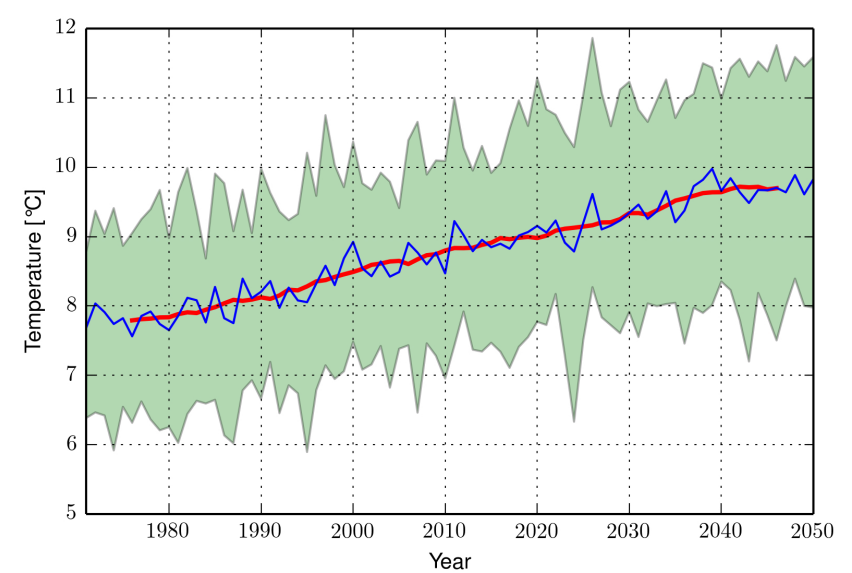

Figure 2. The evolution of the annual (blue line) 10-year (red line) running mean near-surface temperature from 1970 to 2050 averaged over the domain as an ensemble mean of regional climate models from the EURO-CORDEX initiative. The green shade stands for the 10-90\% ensemble percentiles. For future years, models follow the RCP 4.5 scenario.

tals and, for JJA, by an overestimation of sulfate formation; (4) underestimation of $\mathrm{PM}_{2.5}$ in DJF, the main contributors to this bias being the underestimation of nitrate aerosol and both black and organic carbon.

Regarding the meteorological validation, the average 2001-2010 model results are compared to E-OBS (version 12.0) gridded observational data described by van der Besselaar et al. (2011). Data are available on a 0.25 and $0.5^{\circ}$ regular lat-lon grid (roughly $15 \mathrm{~km} \times 20 \mathrm{~km}$ at the modelled latitudes), which were interpolated to the model grid $(10 \mathrm{~km} \times 10 \mathrm{~km})$. Seasonal differences for the near-surface temperature and total precipitation are presented in Fig. 3 and 4 , in ${ }^{\circ} \mathrm{C}$ and $\mathrm{mm} \mathrm{day}^{-1}$ respectively. Temperature is mostly underpredicted by around -0.5 to $-1.5^{\circ} \mathrm{C}$, mostly in DJF and MAM (spring) and to a slightly smaller extent in JJA and SON (autumn). What is more striking, however, is the large negative-biased, but also positive-biased behaviour over the Alps where the model-observation difference can reach $4{ }^{\circ} \mathrm{C}$ in an absolute sense.

Precipitation is usually overpredicted over the domain, mostly during MAM and JJA, by up to $2-3 \mathrm{~mm}^{\text {day }}{ }^{-1}$. Again, large biases are modelled over the mountainous regions, mainly the Alps but also over the eastern Carpathians at the south-eastern edge of the domain, where it can reach $4 \mathrm{~mm} \mathrm{day}^{-1}$ in absolute numbers (precipitation decreases are modelled as well).

The negative temperature bias is clearly seen on the annual temperature cycle in Fig. 5 (upper). The domain-averaged bias is almost zero during the months May-July and is largest during the preceding (February-April) and following months (August). The overprediction of precipitation is striking on the annual cycle plot. During the warm season, it can reach $60-80 \%$. The encountered model biases including their causes are discussed later.

\subsection{The modelled species concentrations}

As the climate impact of urban emissions is calculated considering the radiative effects of $\mathrm{O}_{3}$, sulfates $\left(\mathrm{PSO}_{4}\right)$, nitrates $\left(\mathrm{PNO}_{3}\right)$, primary organic aerosol (POA) and primary elementary carbon (PEC), we will show the distribution of these species only. The horizontal distributions of the average DJF and JJA impacts on surface concentrations for the present and future periods are plotted in Figs. 6 and 7. In winter, ozone is strongly titrated by urban emissions (i.e. by the first order $\mathrm{NO}+\mathrm{O}_{3}$ removal), decreasing by up to $10 \mathrm{ppbv}$ over urban centres which corresponds to a $-50 \%$ decrease. However, ozone decreases over rural areas as well, often by $5-10 \%$. In JJA, ozone titration dominates over urban centres (with up to $50 \%$ decrease similar to DJF), however, further away over rural regions and especially over the eastern part of the domain, a slight ozone production occurs up to $0.5 \mathrm{ppbv}$, corresponding to a $0.5-1 \%$ increase.

The emission contribution to $\mathrm{PSO}_{4}$ burden in DJF reaches $2-3 \mu \mathrm{g} \mathrm{m}^{-3}$ over cities in western Germany and is usually $0.4 \mu \mathrm{g} \mathrm{m}^{-3}$ over other cities, contributing to the total sulfate by up to $30 \%$. The JJA sulfate enhancement due to city emission is larger than in DJF, reaching $4 \mu \mathrm{g} \mathrm{m}^{-3}$ (or $40 \%$ contribution) over urban areas.

Urban emissions usually contribute to nitrates in DJF by more than $5 \%$, while in the cities this increases up to $70 \%$. In absolute numbers, this means an increase of about 1$1.5 \mu \mathrm{g} \mathrm{m}^{-3}$ (most dominantly over the Ruhr area in Germany). In JJA, the absolute contribution of urban emission to the total $\mathrm{PNO}_{3}$ is larger and exceeds $0.2 \mu \mathrm{g} \mathrm{m}^{-3}$ over rural areas as well. However, in relative numbers, the contribution is smaller than in DJF, with maximum values over eastern Europe (up to $20 \%$ ).

The urban emission contribution to POA and PEC is similar, being slightly higher in winter months (4-6\% over large areas). Over cities, the contribution reaches $2 \mu \mathrm{g} \mathrm{m}{ }^{-3}$ for both species and seasons, corresponding to a contribution of $70 \%$.

The vertical distribution of species averaged over the domain $y$ axis (i.e. in $\mathrm{S}-\mathrm{N}$ direction) is plotted in Figs. 8 and 9 for DJF and JJA respectively. Ozone titration is characteristic for the lower model levels, especially for the months DJF, causing $\mathrm{O}_{3}$ decreases which reach -0.8 ppbv up to 150 $200 \mathrm{~m}$ in a vertical direction, corresponding to $5 \%$ decrease due to urban emissions. Furthermore, in winter, the whole of the modelled atmosphere over the domain is subject to ozone destruction. In JJA, $\mathrm{O}_{3}$ destruction over urban areas takes place mainly over the western part of the domain (up to $300 \mathrm{~m}$ in height). Over the eastern part, ozone usually increases on all model levels with most ozone produced (up to $0.2 \mathrm{ppbv}$ ) between heights of 100 and $1000 \mathrm{~m}$. This represents an increase up to $0.5 \%$. 

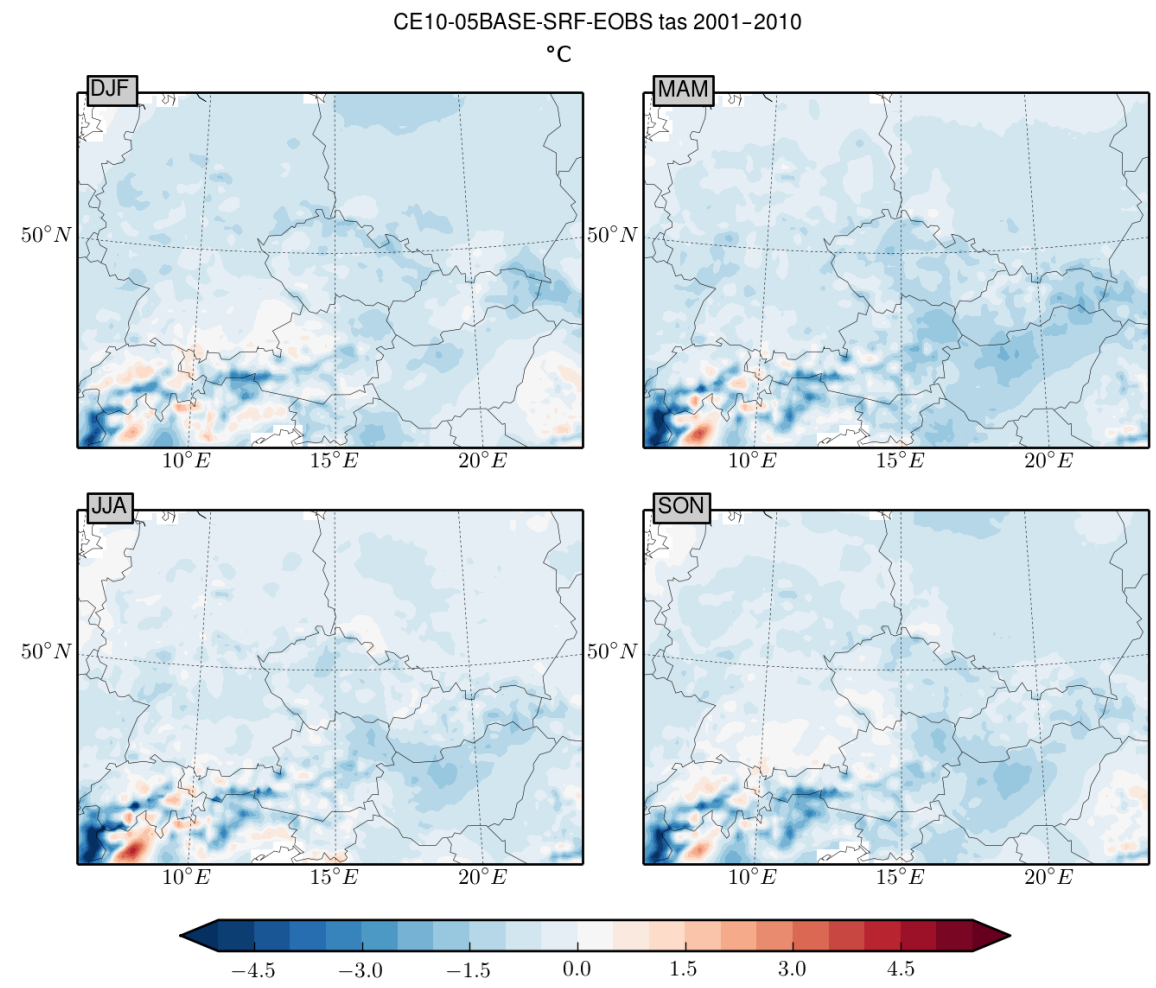

Figure 3. Comparison of the modelled seasonal near-surface temperatures averaged for the 2001-2010 period with the E-OBS observational data in ${ }^{\circ} \mathrm{C}$.
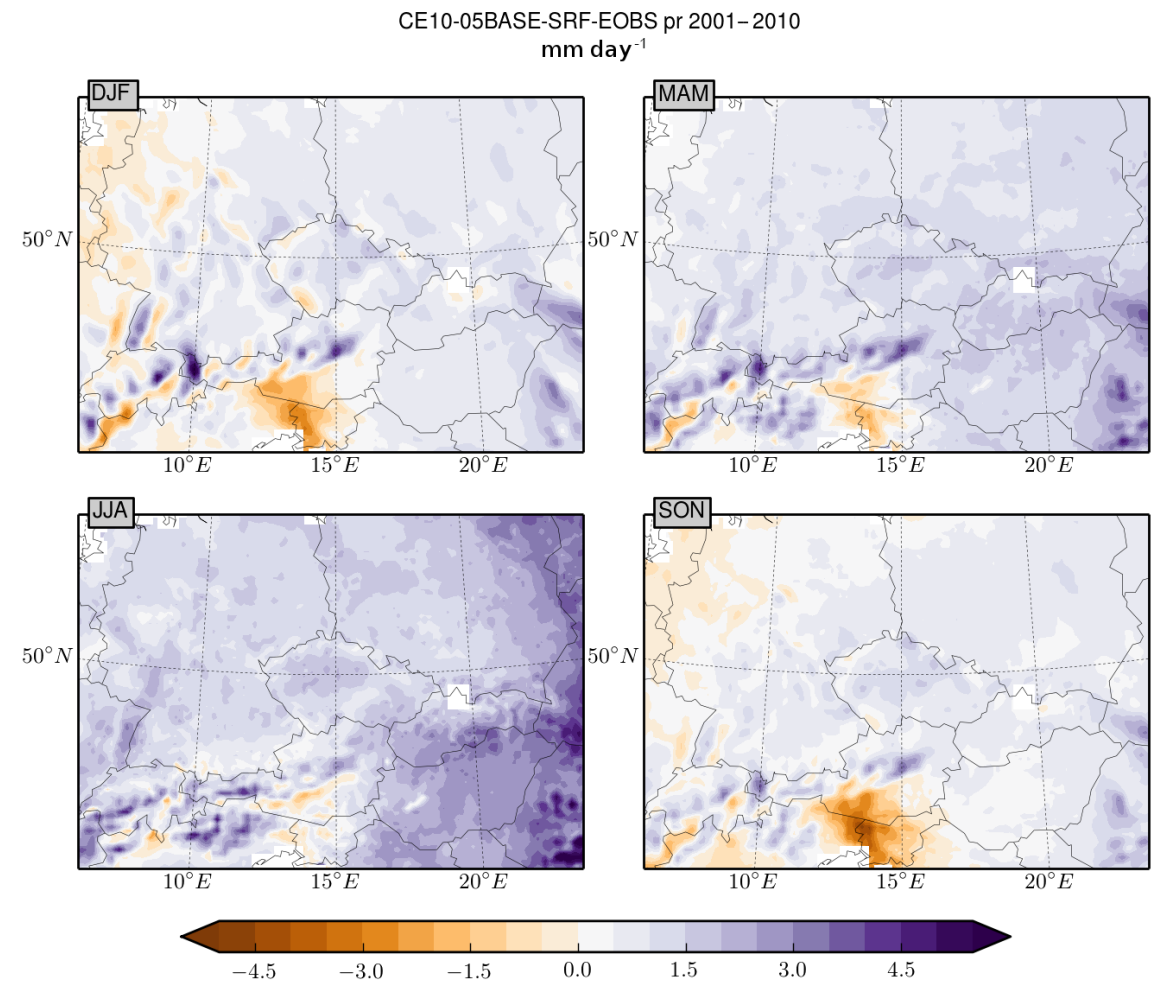

Figure 4. Comparison of the modelled seasonal total precipitation (convective and large scale) averaged for the 2001-2010 period with the E-OBS observational data in $\mathrm{mm} \mathrm{day}^{-1}$. 

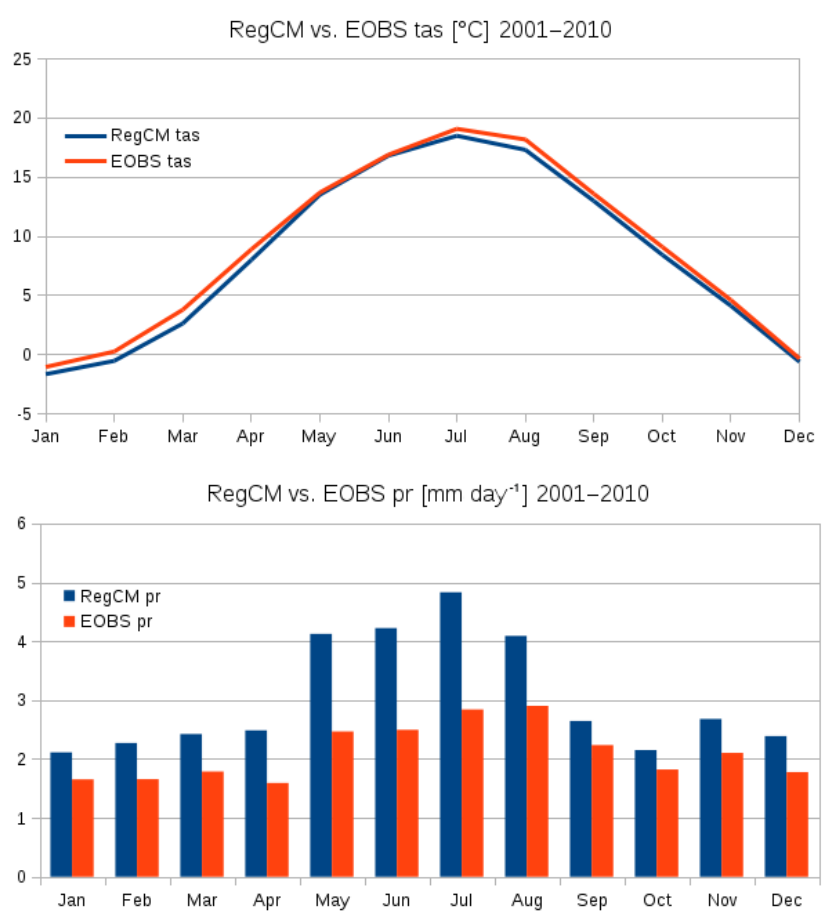

Figure 5. The comparison of the modelled domain-averaged annual cycle with observations for near-surface temperature $\left({ }^{\circ} \mathrm{C}\right)$ and precipitation $\left(\mathrm{mm} \mathrm{day}^{-1}\right)$.

The urban-induced sulfate contribution to the total $\mathrm{PSO}_{4}$ is limited to lower heights in DJF ( $1 \%$ contribution up to $1 \mathrm{~km}$ ) than in JJA ( $1 \%$ contribution up to $7 \mathrm{~km}$ ). However, in absolute numbers, the vertical contribution is only slightly higher in JJA than in DJF and usually negligible over $1 \mathrm{~km}$. The absolute nitrate contribution (third column in both figures) is very low in DJF and is much more significant in JJA. However, in relative numbers, due to lower background $\mathrm{PNO}_{3}$, the winter urban contribution remains larger than $8 \%$, up to $1.7 \mathrm{~km}$ in the vertical extent. Urban emissions contribute to black and organic carbon in a similar manner with significant contribution in the lowest two model levels (i.e. up to $150 \mathrm{~m}$ ) and the contributions are higher in DJF. The PEC and POA contributions are higher than $1 \%$ for the entire vertical extent of the domain in JJA, while in winter this is true up to only about $5 \mathrm{~km}$.

According to Fig. 1, future $\mathrm{NO}_{x}$ and NMVOC emissions usually decrease, except for eastern Europe. This is reflected in the urban impact on ozone in the future period. In winter, the modelled ozone titration is smaller in magnitude for the whole domain, as seen on Fig. 6 as well as on the vertical distribution in Fig. 8. According to Figs. 7 and 9, the future urban-emission-induced ozone changes in JJA are, similarly to DJF, smaller in magnitude. This means reduced titration over cities; however the slight ozone production seen especially over eastern Europe is suppressed as well.
Looking at sulfates in both seasons, due to a drastic decrease of $\mathrm{SO}_{2}$ emissions, a clear decrease is modelled for $\mathrm{PSO}_{4}$ as well, especially over eastern Europe, where in 2005 $\mathrm{SO}_{2}$ was still high and emissions control measures had a larger effect. Sulfates increase only over very few urban areas, where $\mathrm{SO}_{2}$ emission are mainly from SNAP activity sectors 2 and 3 that increase emissions in future, as projected by TNO (see Sect. 2.3).

A somewhat different change is projected for the urbaninduced $\mathrm{PNO}_{3}$ change. While in summer, a decrease is simulated due to $\mathrm{NO}_{x}$ emissions reductions, the picture is more complicated in DJF. Nitrates are formed via neutralisation of nitric acid by available ammonia forming ammonium nitrate $\mathrm{NH}_{4} \mathrm{NO}_{3}$ (Wang et al., 2013). As in the future, less $\mathrm{SO}_{2}$ is projected in general and less ammonia will neutralise sulfates (forming ammonium sulfates, $\left.\left(\mathrm{NH}_{4}\right)_{2} \mathrm{SO}_{4}\right)$, thus more is preserved to form ammonium nitrates. This might explain the winter increase of nitrates in the future due to urban emissions, despite the fact that $\mathrm{NO}_{x}$ emissions are reduced. This increase is most evident over eastern Europe, where the decrease in sulfate is largest and ammonia emissions increase slightly.

The urban-induced black and organic carbon perturbation for future emissions in DJF shows a slight decrease over eastern Europe due to generally larger emissions of $\mathrm{PM}_{2.5}$, of which PEC and POA represent an important fraction. In summer, the 2046-2055 PEC and POA urban perturbations are rather similar to the present-day values with large decreases over western Europe.

\subsection{Impact on climate}

By absorbing the longwave radiation from the surface, ozone acts as a greenhouse gas. Aerosols interact with shortwave solar radiation directly or by modifying the cloud optical properties. Consequently, their perturbation shown in the previous subsections can lead to perturbation in the radiative balance of the atmosphere, hence it may impact climate. Here we will show the impacts for the cold and warm periods of the year (DJF and JJA) on the following parameters: nearsurface temperature, temperature on higher model levels and planetary boundary layer height (PBL). The impacts on precipitation and wind speed are not shown as the results showed to be very noisy and statistically insignificant in both DJF and JJA for the present period as well as for the future period. In each figure, shaded areas represent statistically significant changes on the $98 \%$ confidence level.

Figure 10 shows the DJF and JJA impacts of urban emissions on the near-surface temperature using the present-day (2001-2010) and future (2046-2055) emissions. In winter, a clear temperature decrease is modelled which is statistically significant, especially over eastern Europe (mainly Slovakia and Hungary), and reaches $-0.015 \mathrm{~K}$ change. A relatively stronger cooling is also calculated over the Ruhr area in Germany, up to $-0.02 \mathrm{~K}$. Larger continuous areas exhibit 

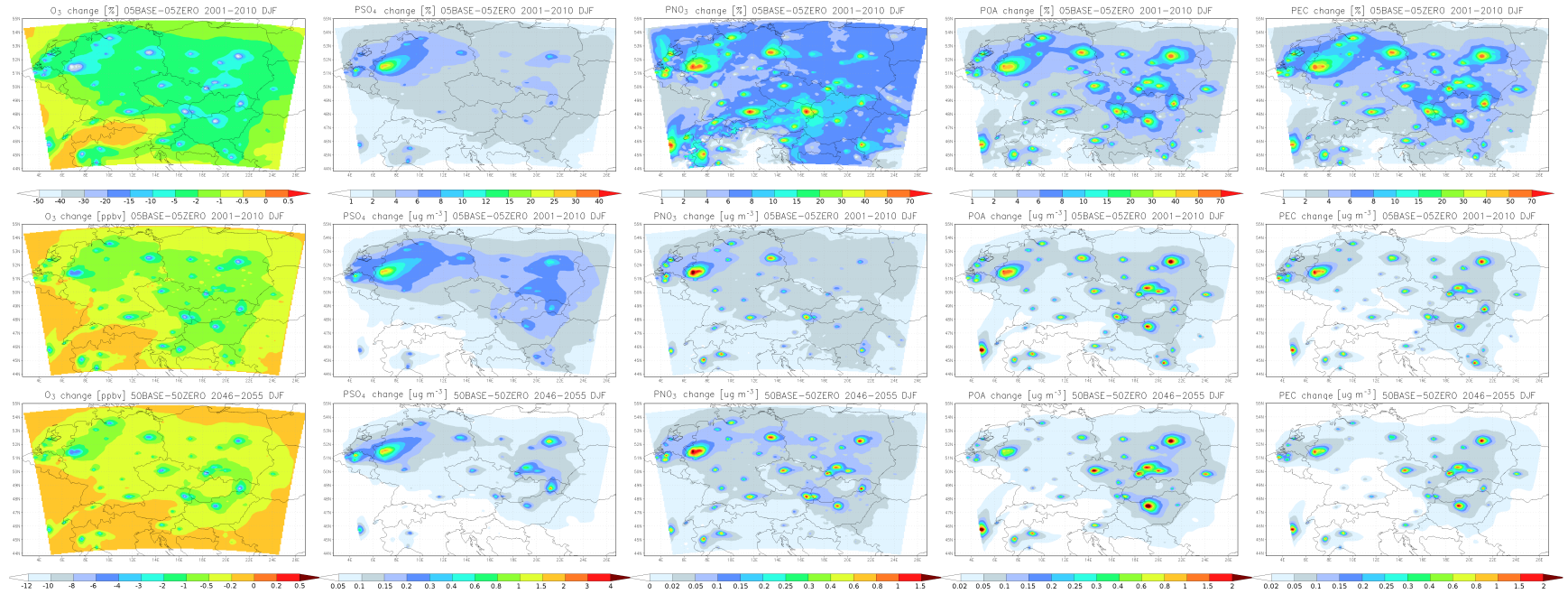

Figure 6. The horizontal distribution of the urban emission impact for DJF. Upper row is the relative impact (for ozone) and relative contribution (for $\mathrm{PSO}_{4}, \mathrm{PNO}_{3}$, POA and PEC) in \% for the present 2001-2010 period; second row is the absolute impact for the present period in ppbv for ozone and $\mu \mathrm{g} \mathrm{m}^{-3}$ for aerosols; the third row is the same as the second row but for the future period (i.e. using future emissions).
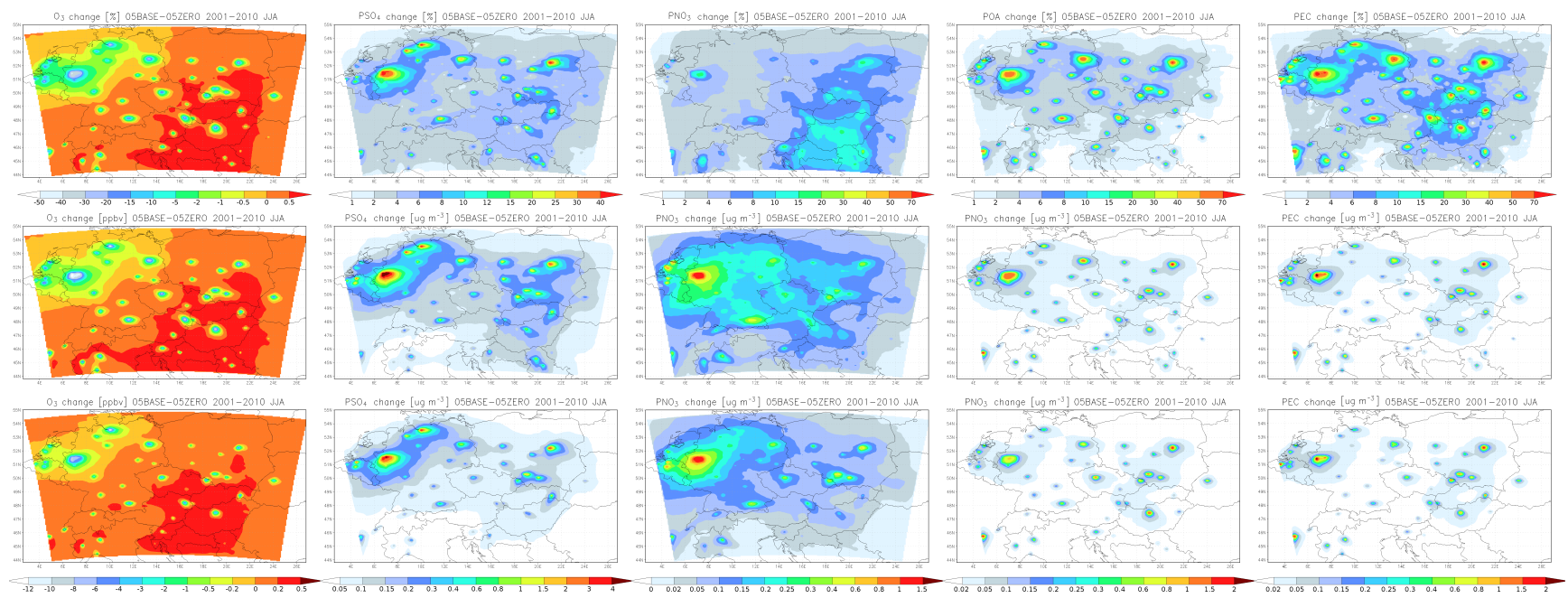

Figure 7. Same as Fig.6 but for JJA.

cooling around $-0.005 \mathrm{~K}$. The JJA picture of the urban emission climate impact is more complicated. Although cooling still dominates the impact, reaching $-0.04 \mathrm{~K}$, especially over south-eastern part of the domain, the area of significance is more fragmented and sometimes a warming is modelled. A few cities are identified where cooling reaches local maximum, e.g. Warsaw, Berlin, Katowice, Prague. With future emissions, the impact on temperature is generally smaller but keeps the pattern from the present-day period, i.e. strongest cooling over eastern Europe reaching $-0.01 \mathrm{~K}$. The future JJA impact again resembles the present-day impact in terms of the spatial pattern, with the strongest statistically significant cooling over eastern/south-eastern Europe. It reaches
$-0.04 \mathrm{~K}$, similarly to the present day, but the corresponding areas with such cooling are clearly smaller than in the present-day period.

To illustrate the importance of performing ensemble simulations and calculating the signal from ensemble mean in order to extract the climate signal from the noise, we present the 2001-2010 JJA near-surface temperature impact from individual ensemble simulations which means $3 \times 3$ possible outcomes in Fig. 11. The figure reveals substantial differences in some areas between individual possibilities of calculating the temperature change. While in each plot, cooling dominates and over some areas (like the Balkans) it is significant in each one, its extent and distribution differs largely. 

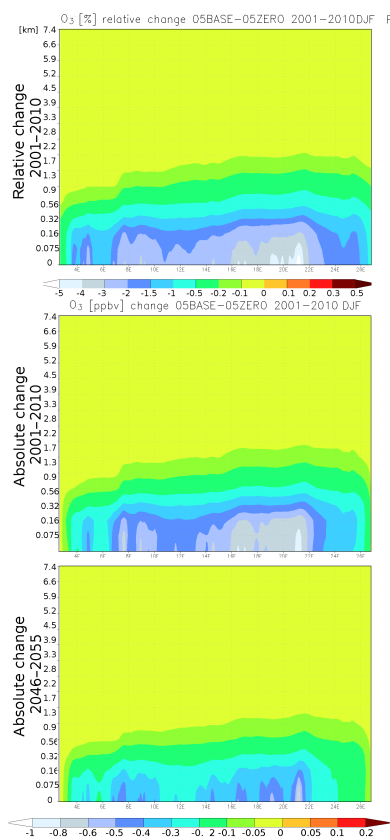
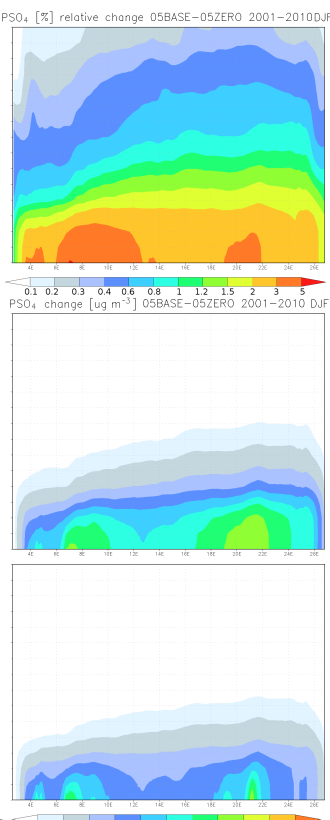

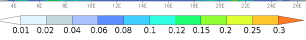
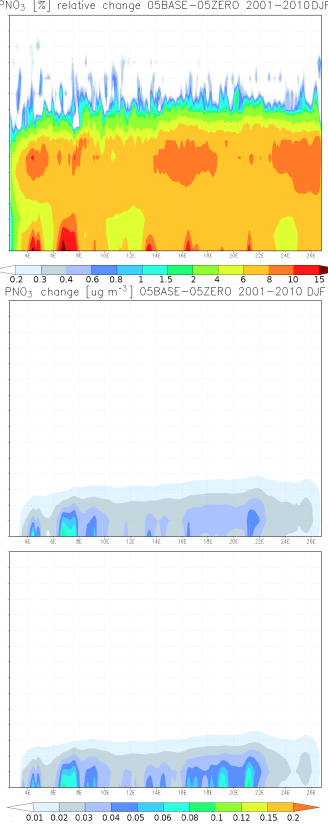
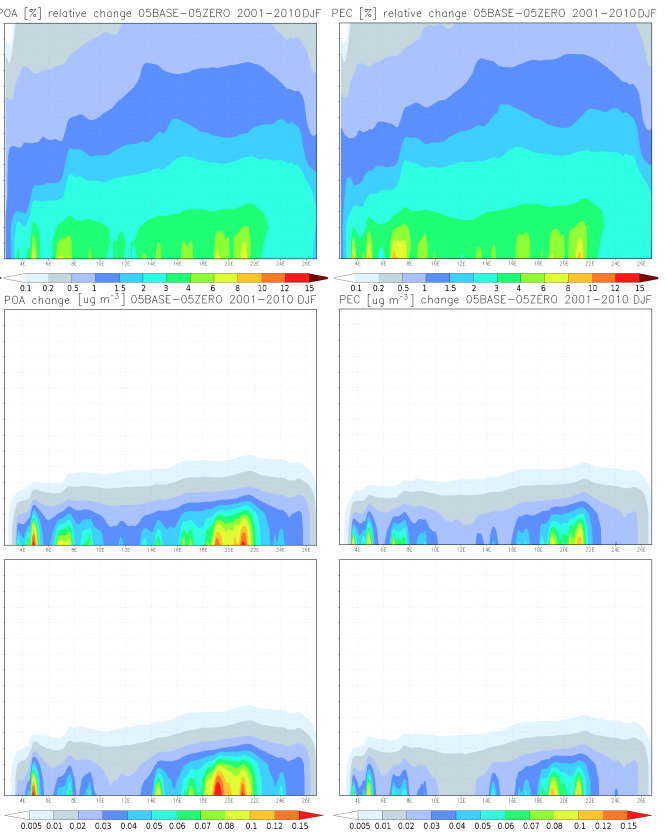

Figure 8. The vertical distribution of the urban emission impact averaged over the domain $y$ axis for winter DJF months. Upper row is the relative impact (for ozone) and relative contribution (for $\mathrm{PSO}_{4}, \mathrm{PNO}_{3}, \mathrm{POA}$ and $\mathrm{PEC}$ ) in \% for the present period; second row is the absolute impact for the present period in ppbv for ozone and $\mu \mathrm{g} \mathrm{m}^{-3}$ for aerosols; the third row is same as the second row but for the future period (i.e. using future emissions).
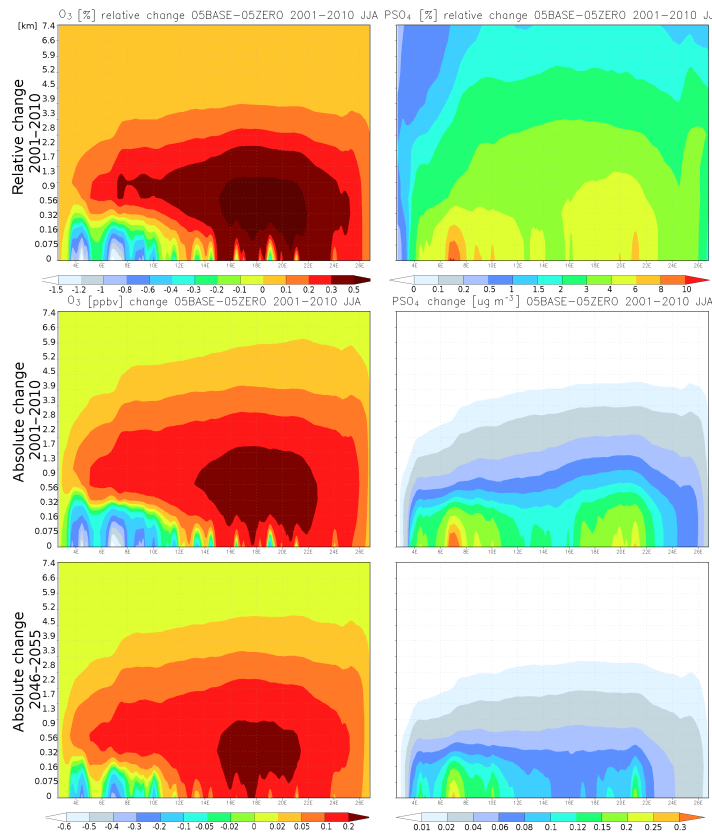
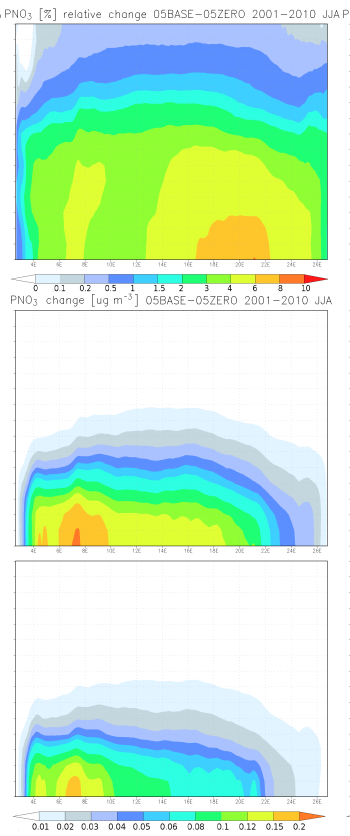
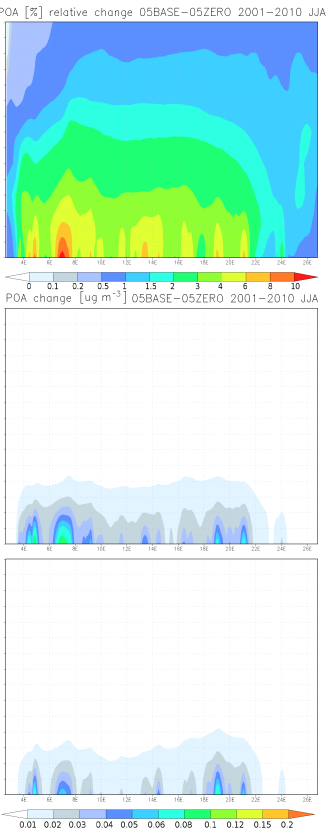
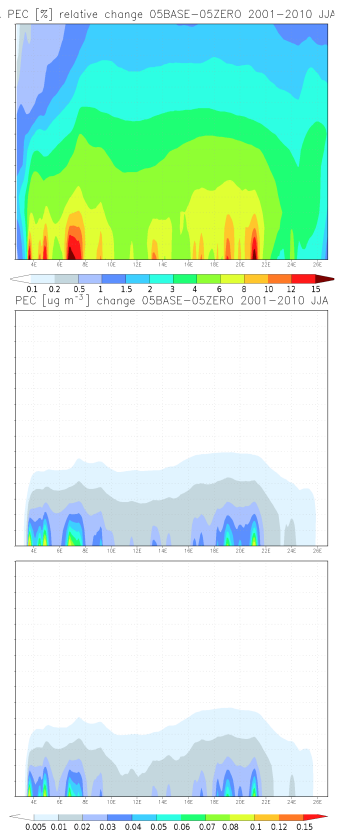

Figure 9. Same as Fig.8 but for JJA.

There are also differences in the areas of warming: over northern Italy, it can reach sometimes $0.08 \mathrm{~K}$. The prevailing cooling also reaches higher absolute values (up to $0.06-$ $0.08 \mathrm{~K}$ ) in individual realisations than calculated from the ensemble means (Fig. 10).
The vertical cross section of the impact averaged over the domain's $y$ axis is plotted in Fig. 12. The temperature decrease due to urban emissions is significant only on the lower levels, up to $200 \mathrm{~m}$ in DJF and $1000 \mathrm{~m}$ in JJA. It is stronger over the eastern part of the domain. Compared to 

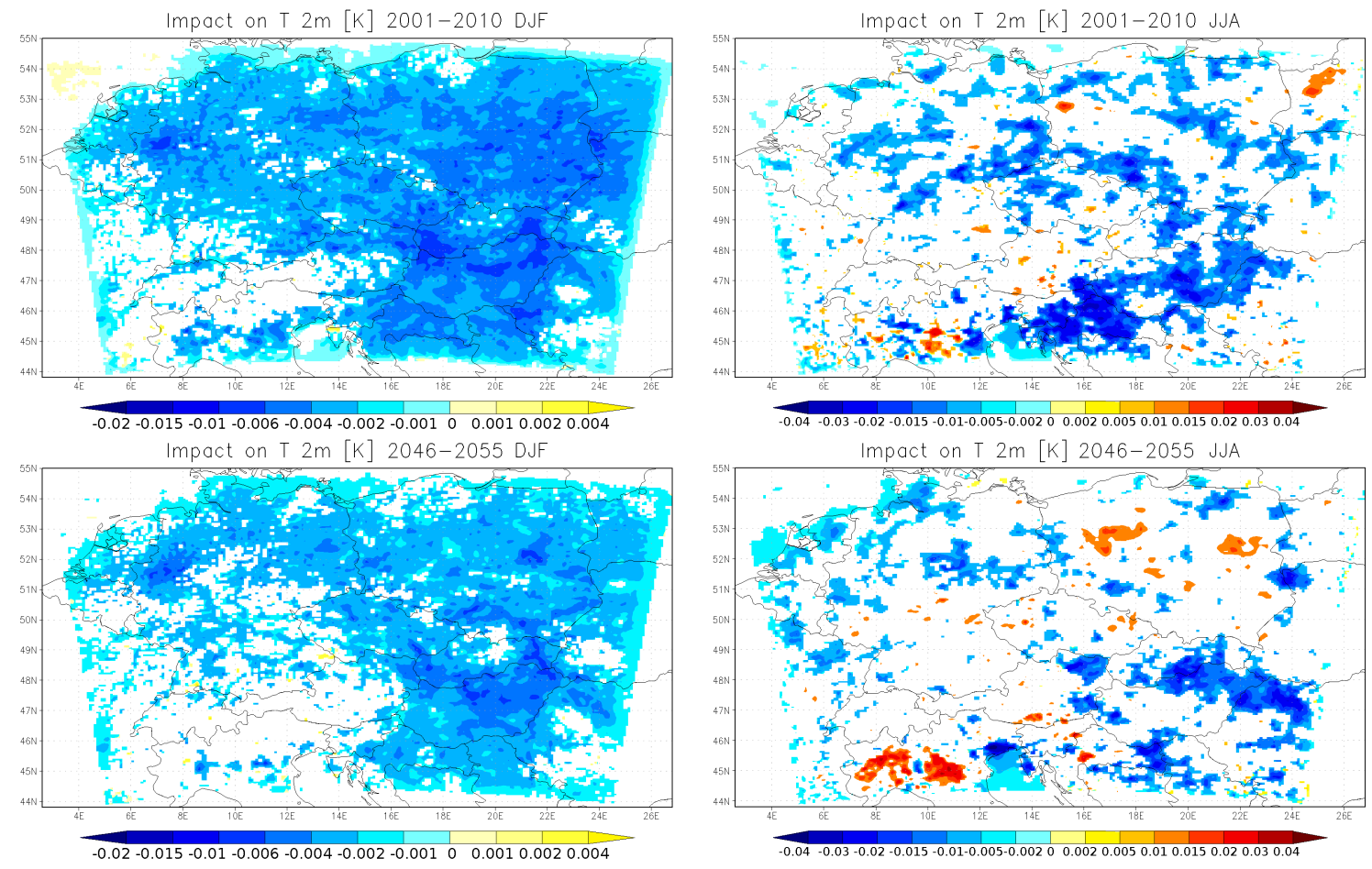

Figure 10. Urban emission impacts on near-surface temperature in K for DJF (left) and JJA (right) for the 2001-2010 (top) period and using future emissions (2046-2055, bottom) calculated from ensemble averages. Shaded areas represent statistically significant differences on the $98 \%$ level.

the vertical distribution of the emission impact on concentrations (Figs. 8 and 9), the statistically significant decrease corresponds to the vertical extent of the urban-emissioninduced species perturbation, especially for secondary inorganic aerosols. For future emissions, the impact is of smaller magnitude and statistically significant only below the first two model levels in DJF (up to $150 \mathrm{~m}$ ). In JJA, the significant impact spreads to higher levels but is limited mostly to the eastern part of the domain. Note that only the first 13 RegCM model levels are plotted.

The impact on surface shortwave (SW) radiation is plotted in Fig. 13. Due to urban-induced aerosol increase, the decrease in surface solar radiation is computed in both DJF and JJA. Especially in DJF, the hotspots of SW radiation reduction correspond well to the location of large cities (decreases of up to $0.6 \mathrm{~W} \mathrm{~m}^{-2}$ ). In summer, the decrease of SW is significant mainly over cities but is larger in magnitude than in DJF, reaching $-1.8 \mathrm{~W} \mathrm{~m}^{-2}$ over the Ruhr area (Germany), Warsaw (Poland). It is high above Berlin (Germany) as well, reaching $-1 \mathrm{~W} \mathrm{~m}^{-2}$. The surface shortwave radiation decrease due to future urban emissions is smaller than the present-day impact (by about $50 \%$ in JJA), which is in line with the modelled temperature decrease. Only over parts of central and eastern Europe, does SW radiation decrease due to cities more than in the present day, which is in close correlation with the increased particulate emissions (seen in
Fig.1) and consequently increased urban-induced perturbation.

The impact on the height of the planetary boundary layer (PBL) is shown in Fig. 14. It is characterised by a small but statistically significant decrease in DJF especially over urban areas up to $-2 \mathrm{~m}$. In JJA, the decrease dominates and reaches $-6 \mathrm{~m}$ (over the Balkan region, Ruhr area, Berlin, Warsaw etc.). Certain areas exhibit increases of PBL height (over western Poland, northern Italy), which is probably due to non-linear feedbacks. These PBL increases, however, cover only a very limited area. The impact PBL height in future DJF reaches similar or slightly smaller values, which is also visible for JJA, when PBL decreases significantly over a fragmented regions across the domain, with a slight dominance over eastern Europe.

We are further interested in whether the temperature impacts seen in Figs. 10 and 12 exhibit some diurnal variation. Thus, we plotted in Fig. 15 the average diurnal cycle of the vertical profile of the domain-averaged impact on temperature for DJF and JJA seasons (only for the presentday period). The simulated cooling seen in Fig. 12 is captured in diurnal cycle as well, but most importantly, this figure indicates that the cooling is most dominant during afternoon hours with maximum values at 14:00-15:00 UTC (15:00-16:00 local time) in DJF and a bit earlier, at 13:00 14:00 UTC (14:00-15:00 local time) in JJA. Another inter- 


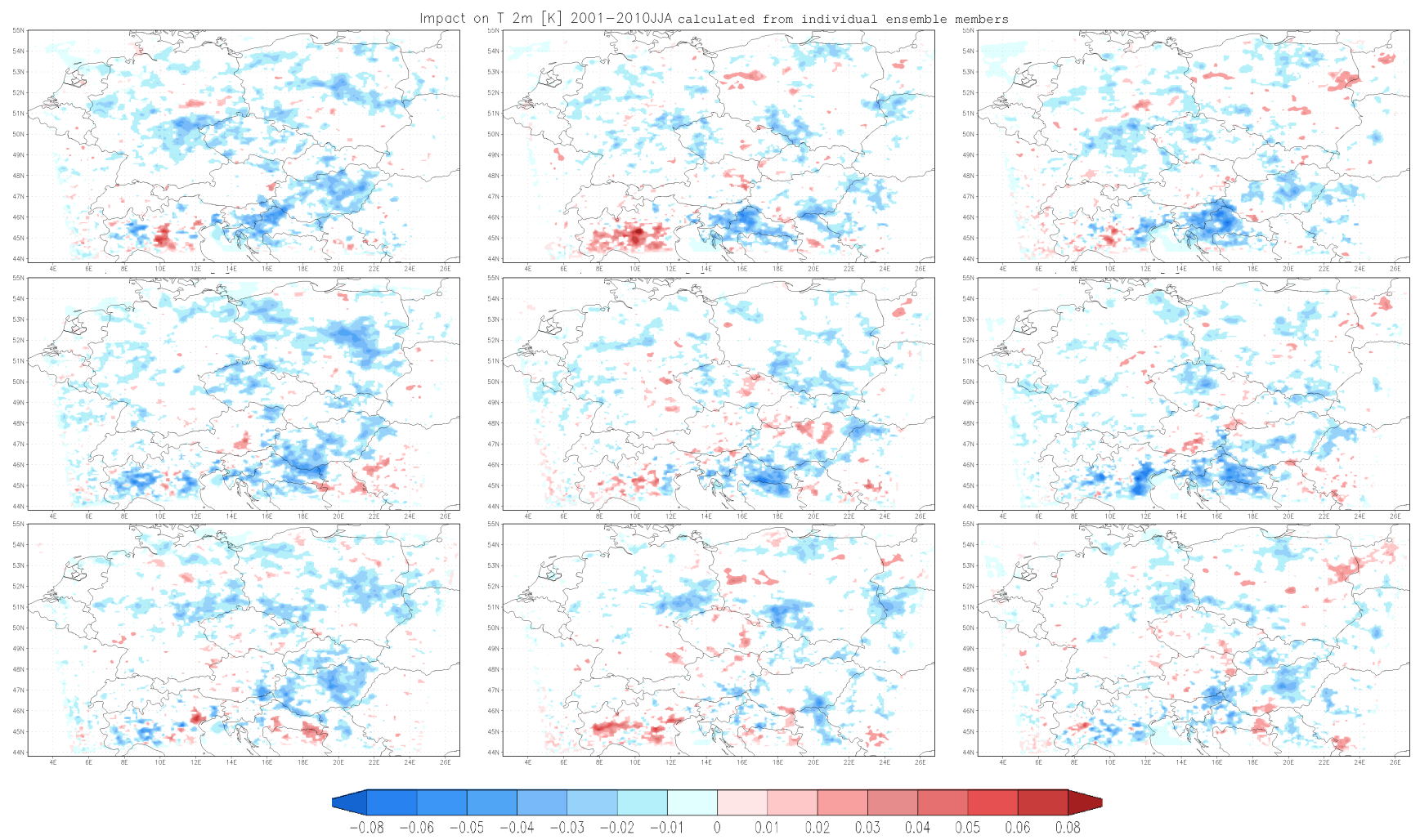

Figure 11. Urban emission impacts on near-surface temperature in K for JJA (2001-2010) calculated from individual ensemble members. Shaded areas represent statistically significant differences on the $98 \%$ level.

esting feature is a formation of warmer air above the cooling layers, which develops almost along with maximum cooling during afternoon hours: in DJF these warming reach maximum slightly shifted to earlier times, while in JJA, it occurs a bit later than the cooling maximum. The layer of warming is thicker in DJF (around 500 m) while in JJA it reaches around $100-200 \mathrm{~m}$ thickness. A further feature is a slight warming on the top of the domain in DJF, however it occurs on the last model layer and is most probably an artefact in connection with the boundary conditions imposed.

To gain an idea of how the urban-induced climate changes (in connection with the chemistry perturbations seen in Figs. 6-9) contribute to the radiative effects of all aerosols, we plotted the near-surface temperature impact of all sulfates, nitrates, black and organic carbon, i.e. not only those induced by urban emissions (Fig. 16). Because of these aerosols, statistically significant cooling dominates the whole domain in both seasons. In DJF, it reaches cooling over $0.2 \mathrm{~K}$ across most of the modelled region and is highest over eastern Europe (up to $-0.4 \mathrm{~K}$ cooling). In JJA, the cooling is of smaller magnitude (usually over $0.1 \mathrm{~K}$ ), with highest levels over central and south-eastern Europe (up to $-0.2 \mathrm{~K}$ ).

\section{Discussion and conclusions}

The evaluation of the RegCMCAMx modelling system from the meteorological point of view showed two main bias behaviours: a general underestimation of near-surface temperatures and a large overestimation of precipitation. Over Europe, Torma et al. (2008) and later Torma et al. (2011) modelled the present-day climate over central Europe with an earlier version of RegCM at the same horizontal resolution and found this negative bias as well. They showed that this underestimation was a result of overestimating cloudiness which caused less solar radiation insolating the surface. The enhanced cloudiness is also linked to the large positive precipitation bias modelled by Torma et al. (2011) and ourselves. They tried to reduce it by tuning parameters controlling cloud/precipitation microphysics; in particular by reducing the autoconversion rate, increasing the raindrop evaporation rate and reducing the raindrop accretion rate. However, after this tuning some positive precipitation still remained. The overpredicted cloudiness and resulting precipitation is probably a consequence of too much water vapour entering the air from the surface. Indeed, Winter et al. (2009) showed that the BATS surface scheme (used here and by Torma et al., 2011) largely overestimates evapotranspiration and the associated latent heat flux (which also contributes to the negative 

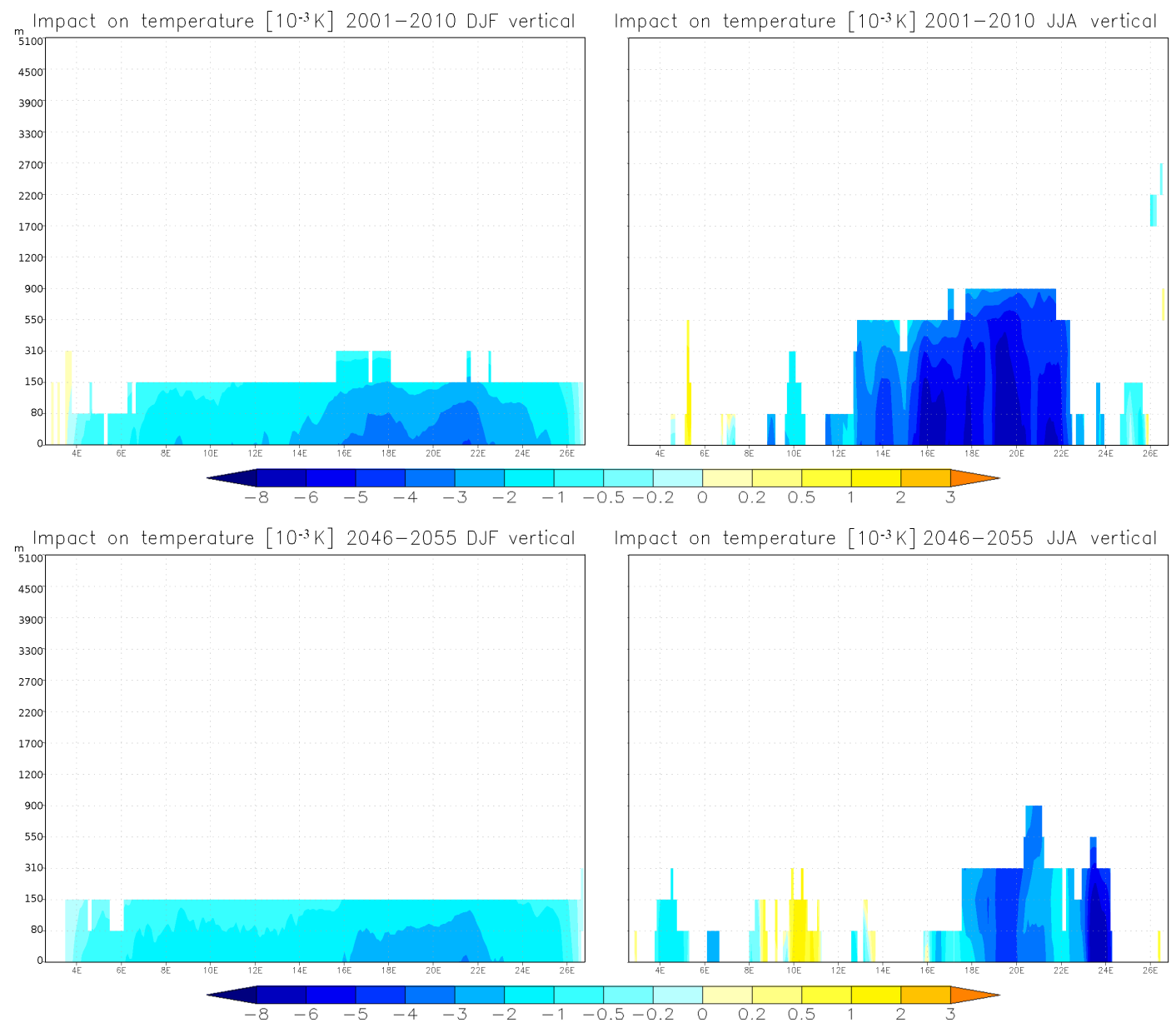

Figure 12. The $y$ axis averaged vertical distribution of the urban emission impacts on temperature in K for DJF (left) and JJA (right) for the 2001-2010 (top) period and using 2046-2055 (bottom) emissions calculated from ensemble averages. Shaded areas represent statistically significant differences on the $98 \%$ level.

surface temperature bias). Later, Wang et al. (2015) confirmed this as well by comparing the newer CLM4.5 landsurface module with the older BATS within the RegCM4 model. Our model further encounters large biases over mountainous areas, mainly the Alps. It has to be realised that the model orography here, even at $10 \mathrm{~km} \times 10 \mathrm{~km}$ resolution, is relatively smooth and not able to resolve mountains peaks and valleys correctly, hence the model surface is either much lower or much higher than the real orography, which significantly determines the observed temperature (in EOBS data). In connection with the model-produced precipitation errors over mountains, another factor can play role as well. Torma et al. (2011) and Zanis et al. (2015), using an earlier version of RegCM and performing experiments with similar resolution, concluded that the Grell convective scheme tends to overestimate precipitation on the windward slopes and consequently produces less precipitation on the leeward. This is seen in the precipitation bias, which is negative on one side of the model-resolved mountain ridges and positive on the other side.

The modelled ozone distribution showed that urban emissions over central Europe cause, on average, ozone reduction due to titration. Im et al. (2011a, b) had a similar conclusion: due to its reaction with $\mathrm{NO}$, ozone is destroyed near the sources; however where $\mathrm{NO}_{x}$ is further mixed with additional NMVOC (including of biogenic origin), the odd oxygen present in $\mathrm{NO}_{2}$ becomes available to produce ozone further downwind. The vertical figures reveal that this happens mainly over eastern Europe with less dense urban emissions, more rural air available and at higher altitudes.

The aerosols perturbation for the primary aerosols (black and organic carbon) is limited to the source regions and spans a small vertical extent, mostly residing in the boundary layer that is, in general, thinner in DJF than in JJA. The secondary formed sulfates and nitrates of urban origin occupy much ticker atmospheric layer especially in JJA, due to higher vertical mixing in summer. Sulfate concentrations dif- 

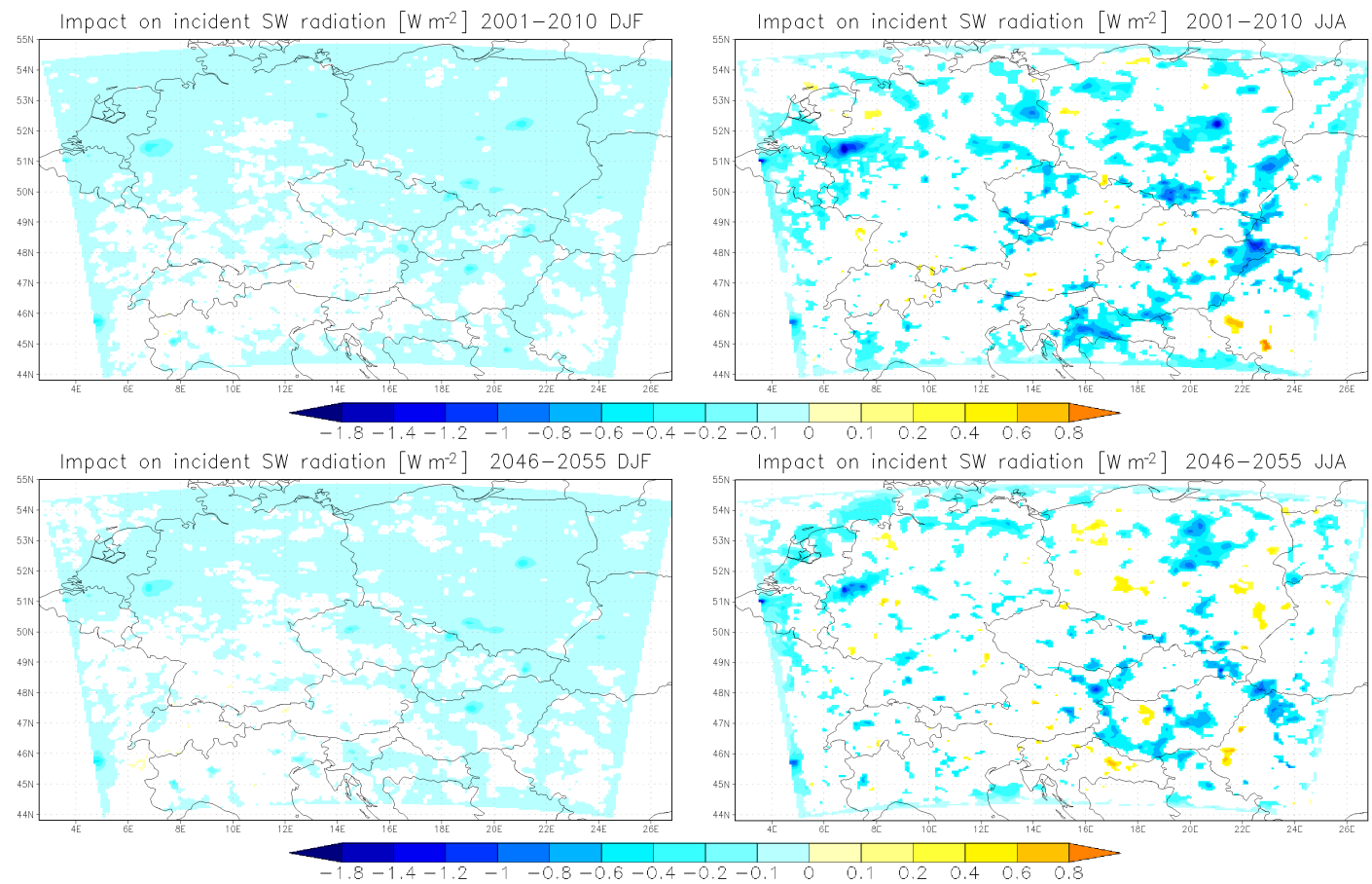

Figure 13. Urban emission impacts on the solar incident radiation at the surface in $\mathrm{W} \mathrm{m}^{-2}$ for DJF (left) and JJA (right) for the 2001-2010 (top) period and using 2046-2055 (bottom) emissions calculated from ensemble averages. Shaded areas represent statistically significant differences on the $98 \%$ level.
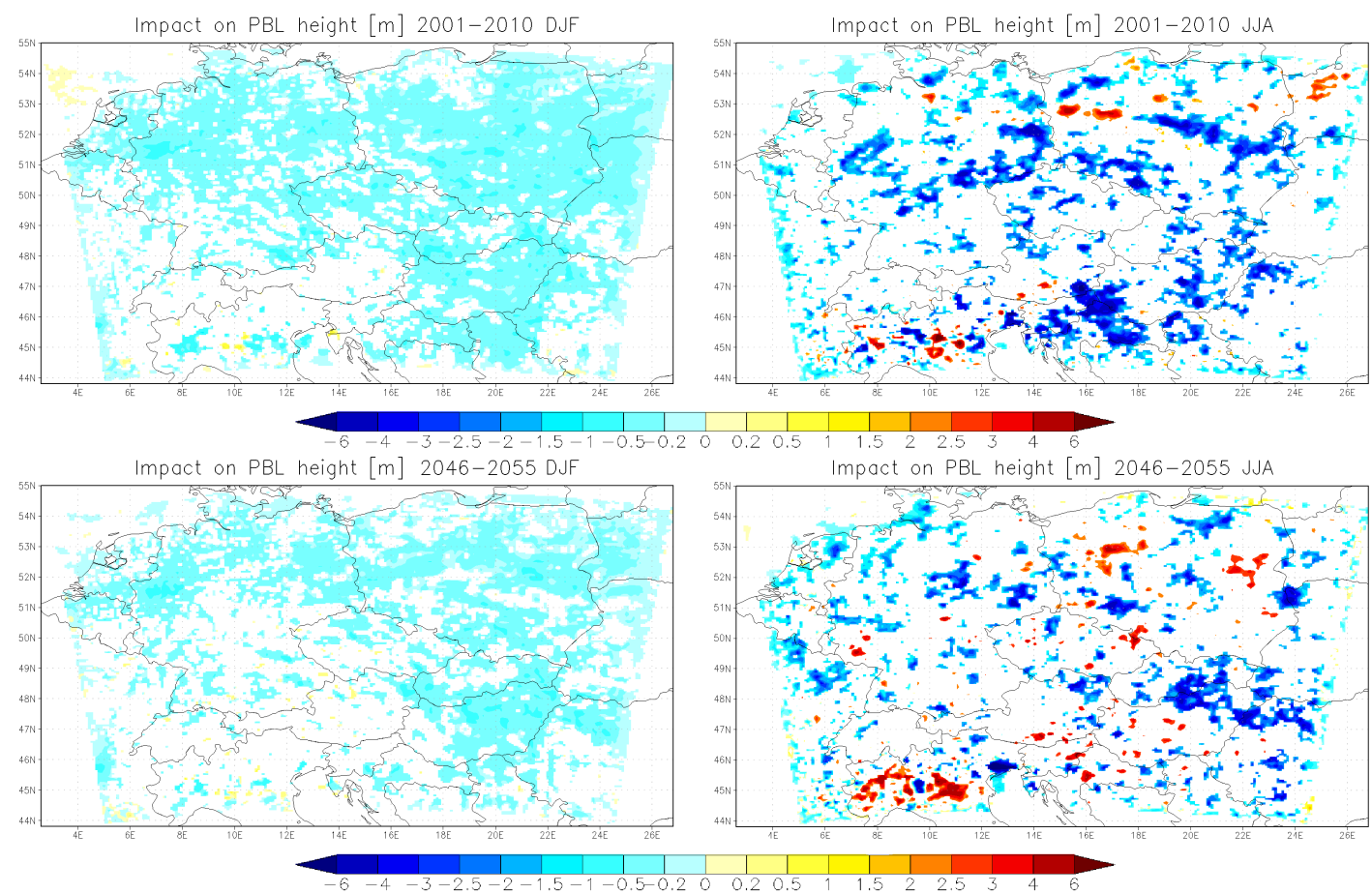

Figure 14. Urban emission impacts on the planetary boundary layer height in metres for DJF (left) and JJA (right) for the 2001-2010 (top) period and using 2046-2055 (bottom) emissions calculated from ensemble averages. Shaded areas represent statistically significant differences on the $98 \%$ level. 

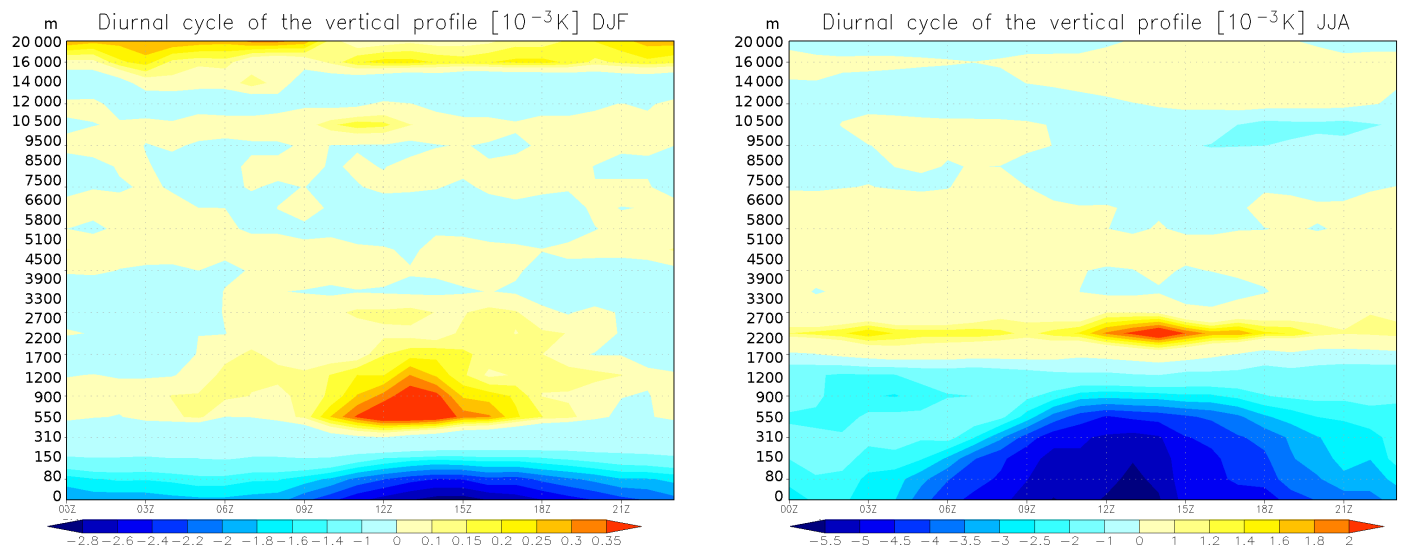

Figure 15. Urban emission impacts on temperature: the diurnal cycle of the horizontally averaged vertical profile in $10^{-3} \mathrm{~K}$ for DJF and JJA, present-day period (2001-2010).
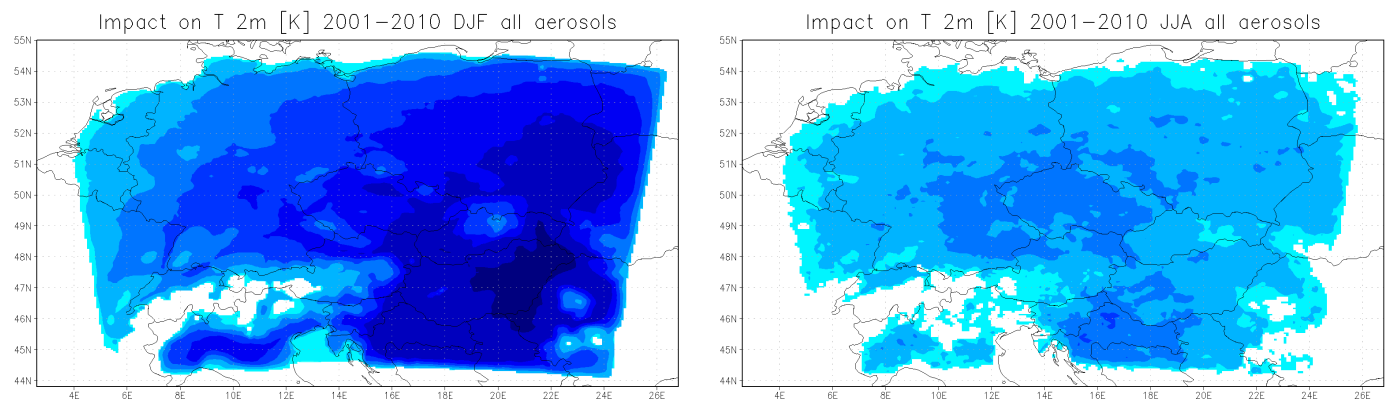

Figure 16. Impact of aerosols ( $\mathrm{PSO}_{4}, \mathrm{PNO}_{3}, \mathrm{POA}$ and PEC) on near-surface temperature in $\mathrm{K}$ for DJF (left) and JJA (right) for the 20012010 period. Shaded areas represent statistically significant differences on the $98 \%$ level.

Vertical profile of the impact on $\mathrm{PNO}_{3}\left[\mu \mathrm{g} \mathrm{m}^{-3}\right]$

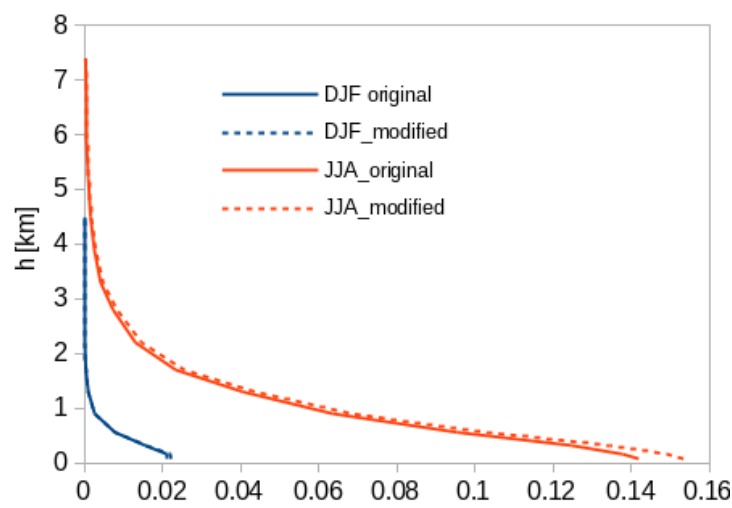

Figure 17. The effect of reduction of precipitation bias (i.e. decreasing precipitation by about $30 \%$ ) on the vertical profile of the urban emission impact on the nitrates aerosols for DJF (blue) and JJA (red). Solid lines show the original simulations with bias, the dashed lines stand for the reduced precipitation case. Period covered: 2001-2005. Units: $\mu \mathrm{g} \mathrm{m}^{-3}$. fer between the two seasons only slightly, as modelled similarly by Schaap et al. (2004). On the other hand, the nitrates show a significant seasonal variation. The low values in winter are connected to much less available ammonia emissions that would form ammonium nitrates. Elevated ammonia concentrations are essential to stabilise this aerosol at high temperatures, thus higher concentrations of $\mathrm{PNO}_{3}$ are modelled, especially over western Europe where ammonia emissions are also high in JJA (Schaap et al., 2004).

One must bear in mind, that our model simulated a large positive precipitation bias. This probably has a large impact on the modelled species concentrations. To quantify this we performed a sensitivity experiment for the base and zero experiments (05BASE and 05ZERO) where we reduced precipitation by about $30 \%$, according to the monthly bias. The reduction took place in the meteorological preprocessor that translates RegCM meteorological fields to CAMx-ready fields/formats (within the coupled system). The sensitivity simulation covered only the 2001-2005 period. The impact on the vertical distribution of species is shown with the example of nitrates. The effect for other aerosols is similar and the impact on ozone is almost negligible. Figure indicates that 
with reduced precipitation there is a clear increase of concentrations, probably due to reduced wet removal. However, this increase remains under $10 \%$ for both DJF and JJA. Expecting linear response of radiative effects on this small perturbation, this corresponds to a smaller temperature effect of 1 order of magnitude, i.e. only $10^{-3} \mathrm{~K}$. So we can conclude that the impact of precipitation bias on the overall results is minor.

The radiative and, consequently, temperature response is well explained by the urban-induced chemical perturbations. Ozone is mostly destroyed over lower model levels and the production over higher altitudes is very small. This may result in an overall negative radiative forcing and, thus, cooling. However, in the lower troposphere, the main contributor to the total solar and longwave heating/cooling rates is water vapour, whereas rates are very low for ozone and other GHGs (Petty, 2006; Liou, 2002). Thus the modelled ozone perturbations in this part of the atmosphere are expected to have a minor radiative impact.

Aerosol perturbations are purely positive and are limited to the few model levels above the surface. Due to direct and indirect radiative effects and due to the fact that surface albedos over the examined regions do not have high reflectivity (Garcia et al., 2012), this has to result in a decrease in solar radiation impacting the surface and reducing temperature. The temperature response confirms this. The impact is very small in DJF (of order of $10^{-3} \pm 10^{-2}$ ) but statistically significant almost over the whole domain. In winter, weather is characterised, in terms of static stability due to lower insolation, with more stable conditions and reduced variability, thus the climate signal of the urban enhanced aerosol is distinguishable from the reference climate, although it has a very small magnitude.

For major urban emitters like Warsaw, Berlin or the Ruhr area, the temperature response in winter resembles the location of significant solar shortwave radiation decrease. In summer, however, although the SW radiation at surface decrease significantly over many urban areas, the resulting surface temperature response has a different spatial distribution and its maximum does not follow the location of negative peaks in the SW figure. Zanis (2009) and Zanis et al. (2012), who examined the direct radiative impact of anthropogenic aerosol over Europe, presented a similar finding; i.e. the geographic pattern of the aerosol optical depth (AOD) and the changes in the top-of-the-atmosphere radiative forcing (TOA $\mathrm{RF}$ ) do not correspond to near-surface temperature changes and they explain it through the complex role of aerosol in modifying, not only the radiative budget, but having dynamical feedback on the whole atmospheric circulation. Similarly, Roeckner et al. (1999) found a poor correlation between the distribution of forcing and the temperature response in their simulations. Recently, Forkel et al. (2015), using the WRF model, examined the direct/indirect aerosol feedbacks on European meteorological conditions and arrived at a similar conclusion regarding the aerosol distribution and the resulting radiative and climate effects.

The simulated changes in the boundary layer height follow from the overall decrease of lower tropospheric temperatures. The scattering and absorption of aerosols reduce surface radiation, which in turn suppresses sensible heat flux (Yu et al., 2002). The reduced sensible heat reduces temperatures and limits the growth of the boundary layer. The decrease is highest (in both seasons) over urban areas and is much higher in summer when temperature decrease is also higher.

The vertical extent of the statistically significant radiative changes (cooling) is limited to a few model levels in the lower troposphere. This corresponds to the vertical distribution of the chemical perturbations triggered by urban emissions, which encompasses a thicker layer in JJA than in DJF. Similarly, the negative temperature response reaches higher levels in summer. Although there turned out to be statistically insignificant on the $98 \%$ confidence level, a slight warming is modelled over the region. This is not visible on the vertical cross-section figures (due to significance shading), however, it is visible on the diurnal cycle plot where the significance test was omitted. Earlier, Nguimdo and Njomo (2013) also found strong cooling for the lower atmosphere, with slight heating in the upper atmosphere. The cooling in the aerosol layer is caused by the reflection of solar radiation from the aerosols, which reduces the amount of solar radiation available for absorption. Above the aerosol layer (in our case the urban triggered enhanced aerosol layer), the reflected radiation becomes available for absorption, thus leading to slight heating in the corresponding atmospheric layers.

We found that the urban-emission-induced cooling in the lower troposphere has a clear diurnal cycle. It follows the variation of the incident solar radiation during the day. In winter, the maximum cooling is shifted towards the later hours. We can attribute this to the diurnal variation of the aerosol concentrations. Figure 18 shows the winter and summer diurnal cycle of the domain-averaged vertical profile for the sum of aerosols considered in radiative calculations. In winter, the maximum values are achieved during afternoon hours, while in JJA, maximum concentrations near the surface are modelled much earlier. This causes the maximum cooling in winter to not occur simultaneously with the maximum insolation, unlike in summer.

The impact of future emissions is, in terms of horizontal and vertical distribution, very similar to the present day. However, due to lower emission in general, it is smaller in magnitude. This is true especially for eastern European countries, where current emissions are still high and rapid reductions are expected in the future (mainly for $\mathrm{SO}_{2}$, as the main precursor for sulfates).

The radiative impact of aerosols triggered by all emissions on surface temperatures is very similar to the numbers in $\mathrm{Za}$ nis et al. (2012) or Forkel et al. (2015). Comparing to the urban emission impact, our results indicate that urban-aerosolinduced cooling (including the secondary ones) contributes 


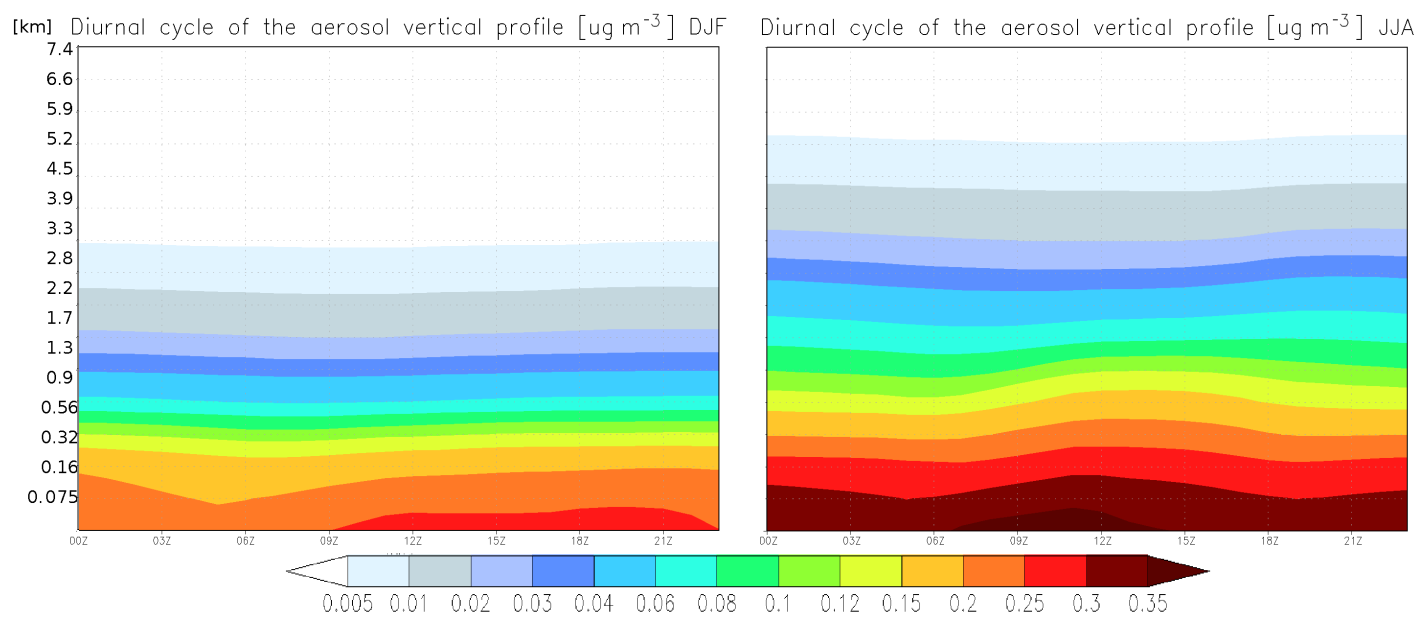

Figure 18. Urban emission impacts on the aerosol concentrations: the diurnal cycle of the horizontally averaged vertical profile in $\mu g^{-3}$ for DJF and JJA, present-day period (2001-2010).

by about $10 \%$ to the total cooling. The question is, why do urban aerosols cause more cooling during JJA than during DJF? This is in contrast to the cooling caused by all the aerosols which is stronger in winter than in summer. It can be explained by the different relative contribution of urban particulate matter to the total aerosol burden. It is clearly seen on the vertical cross section of the perturbation that in JJA, the relative contribution of the urban aerosols is, in general, higher at each model level than in DJF (please note the different colour scales). This is true especially for sulfates and for eastern Europe. Indeed, large emissions from combustion plants are accounted for in this region in DJF, but this is not of urban origin, hence this lower relative contribution to the total aerosol burden.

We can further assume that the radiative impact of urban emission in our simulations is probably underpredicted. We already showed that one reason lies in the positive water vapour-cloudiness-precipitation bias in RegCM. However, here (as shown) the effect is smaller than the signal we achieved, at least by 1 order of magnitude. Furthermore, both meteorological and chemical lateral boundary conditions (LBC) were kept the same for all the simulations. This causes suppression of the signal but this is mainly limited to areas near to the domain edges. At last, we did not consider the radiative effects of secondary organic aerosols (SOA) which also have an important role in regional climate (Kanakidou et al., 2005). It is shown by many (Liggio et al., 2010 and references therein) that secondary organic aerosols comprise a significant part of the organic aerosol (OA) in urban plume; some studies consider POA (primary OA) as the dominant component while others take the opposite view. In our simulations SOA is about $50 \%$ less than POA. Given the fact that POA comprises about $20-30 \%$ of the aerosol we consider in radiation calculation, adding SOA would increase the total aerosol load roughly about $10 \%$. Again, from the linear response assumption for the climate impact it follows that considering SOA would result in a smaller change in the temperature impact by 1 order of magnitude. Conclusively, the radiative impact in our study is underestimated, but only in a small extent, and it is not likely that the aerosol impact from urban emission would change the order of magnitude without these shortcomings.

In Huszar et al. (2014), we examined the climate impact of cities through the meteorological effects triggered by urban canopy. The impact there exceeded $1{ }^{\circ} \mathrm{C}$ in JJA and reached about $0.2^{\circ} \mathrm{C}$ in DJF in absolute values. For both seasons, the absolute climate impact of urban emissions is smaller by more than an order of magnitude. This indicates, at least for central Europe, that regional climate studies concerning the impact of urban environment on the atmosphere should more focus on this first aspect, i.e. on the impact of urban canopy on the meteorology and climate. However, it must be stressed that, while the climate impact of urban emissions is showing to be rather small, the impact on air quality remains significant (Huszar et al., 2016) and has to be considered in the future.

\section{Data availability}

The source code of the models used in this study are freely available: RegCM4.2 model (RegCM, 2016) - http://gforge. ictp.it/gf/project/regcm/frs; the CAMx 5.4 model (CAMx, 2016) - http://www.camx.com/download/default.aspx). The modelled data used for this manuscript is available upon request from the corresponding author, Peter Huszár (peter.huszar@mff.cuni.cz).

Acknowledgements. This work has been funded by the Czech Science Foundation (GACR) project No. 13-19733P and by 
the project UNCE 204020/2013. We further acknowledge the TNO MEGAPOLI emissions data set from the EU-FP7 project MEGAPOLI (http://megapoli.info) as well as the E-OBS data set from the EU-FP6 project ENSEMBLES (http://ensembles-eu.metoffice.com) and the data providers in the ECA\&D project (http://www.ecad.eu).

Edited by: Y. Qian

Reviewed by: three anonymous referees

\section{References}

Amann, M., Bertok, I., Cofala, J., Heyes, C., Klimont, Z., Rafaj, P., Schöpp, W., and Wagner, F.: National Emission Ceilings for 2020 based on the 2008 Climate \& Energy Package. NEC Scenario Analysis Report Nr. 6, International Institute for Applied Systems Analysis (II-ASA), Laxenburg, Austria, 2008.

Angevine, W. M., White, A. B., Senff, C. J., Trainer, M., Banta, R. M., and Ayoub, M. A.: Urban-rural contrasts in mixing height and cloudiness over Nashville in 1999, J. Geophys. Res., 108, 4092, doi:10.1029/2001JD001061, 2003.

Baklanov, A.: Chemical weather forecasting: a new concept of integrated modelling, Adv. Sci. Res., 4, 23-27, doi:10.5194/asr-423-2010, 2010.

Baklanov, A., Lawrence, M., Pandis, S., Mahura, A., Finardi, S., Moussiopoulos, N., Beekmann, M., Laj, P., Gomes, L., Jaffrezo, J.-L., Borbon, A., Coll, I., Gros, V., Sciare, J., Kukkonen, J., Galmarini, S., Giorgi, F., Grimmond, S., Esau, I., Stohl, A., Denby, B., Wagner, T., Butler, T., Baltensperger, U., Builtjes, P., van den Hout, D., van der Gon, H. D., Collins, B., Schluenzen, H., Kulmala, M., Zilitinkevich, S., Sokhi, R., Friedrich, R., Theloke, J., Kummer, U., Jalkinen, L., Halenka, T., Wiedensholer, A., Pyle, J., and Rossow, W. B.: MEGAPOLI: concept of multi-scale modelling of megacity impact on air quality and climate, Adv. Sci. Res., 4, 115-120, doi:10.5194/asr-4-115-2010, 2010.

Baklanov, A., Molina, L. T., and Gauss, M.: Megacities, air quality and climate, Atmos. Environ., 126, 235-249, doi:10.1016/j.atmosenv.2015.11.059, 2016.

Basara, J. B., Hall Jr., P. K., Schroeder, A. J., Illston, B. G., and Nemunaitis, K. L.: Diurnal cycle of the Oklahoma City urban heat island, J. Geophys. Res., 113, D20109, doi:10.1029/2008JD010311, 2008.

Blesl, M., Kober, T., Bruchof, D., and Kuder, R.: Effects of climate and energy policy related measures and targets on the future structure of the European energy system in 2020 and beyond, Energ. Policy, 38, 6278-6292, 2010.

Butler, T. M., Lawrence, M. G., Gurjar, B. R., van Aardenne, J., Schultz, M., and Lelieveld, J.: The representation of emissions from megacities in global emission inventories, Atmos. Environ., 42, 703-719, doi:10.1016/J.ATMOSENV.2007.09.060, 2008.

Butler, T. M., Stock, Z. S., Russo, M. R., Denier van der Gon, H. A. C., and Lawrence, M. G.: Megacity ozone air quality under four alternative future scenarios, Atmos. Chem. Phys., 12, 4413-4428, doi:10.5194/acp-12-4413-2012, 2012.

Butler, T. M. and Lawrence, M. G.: The influence of megacities on global atmospheric chemistry: a modelling study, Environ. Chem., 6, 219-225, doi:10.1071/EN08110, 2009.
CAMx: CAMx 5.4 model, available at: http://www.camx.com/ download/default.aspx, last access: 18 October 2016.

Dickinson, R. E., Henderson-Sellers, A., and Kennedy, P.: Biosphere-atmosphere transfer scheme (BATS) version 1 as coupled to the NCAR community climate model, Tech Rep, National Center for Atmospheric Research Tech Note NCAR.TN387+STR, NCAR, Boulder, CO, USA, 1993.

Dütsch, H. U.: Vertical ozone distribution on a global scale, Pure Appl. Geophys., 116, 511-529, 1978.

Feng, J.-M., Wang, Y.-L., and Ma, Z.-G.: Long-term simulation of large-scale urbanization effect on the East Asian monsoon, Clim. Change, 1-13, doi:10.1007/s10584-013-0885-2, 2013.

Finardi, S., Silibello, C., D'Allura, A., and Radice, P.: Analysis of pollutants exchange between the Po Valley and the surrounding European region, Urban Climate, 10, 682-702, doi:10.1016/j.uclim.2014.02.002, 2014.

Flagg, D. D. and Taylor, P. A.: Sensitivity of mesoscale model urban boundary layer meteorology to the scale of urban representation, Atmos. Chem. Phys., 11, 2951-2972, doi:10.5194/acp-11-29512011, 2011.

Folberth, G. A., Rumbold, S., Collins, W. J., and Butler, T.: Determination of Radiative Forcing from Megacity Emissions on the Global Scale, MEGAPOLI Project Scientific Report 10e08, UK MetOffice Hadley Center, Exeter, UK, 2010.

Folberth, G. A., Rumbold, S. T., Collins, W. J., and Butler, T. M.: Global radiative forcing and megacities, Urban Climate, 1, 4-19, doi:10.1016/j.uclim.2012.08.001, 2012.

Folberth, G. A., Butler, T. M., Collins, W. J., and Rumbold, S. T.: Megacities and climate change - A brief overview, Environ. Pollut., 203, 235-242, doi:10.1016/j.envpol.2014.09.004, 2015.

Forkel, R., Balzarini, A., Baró, R., Bianconi, R., Curci, G., JiménezGuerrero, P., Hirtl, M., Honzak, L., Lorenz, C., Im, U., Pérez, J. L., Pirovano, G., San José, R., Tuccella, P., Werhahn, J., and Zabkar, R.: Analysis of the WRF-Chem contributions to AQMEII phase 2 with respect to aerosol radiative feedbacks on meteorology and pollutant distributions, Atmos. Environ., 115, 630-645, 2015.

Freney, E. J., Sellegri, K., Canonaco, F., Colomb, A., Borbon, A., Michoud, V., Doussin, J.-F., Crumeyrolle, S., Amarouche, N., Pichon, J.-M., Bourianne, T., Gomes, L., Prevot, A. S. H., Beekmann, M., and Schwarzenböeck, A.: Characterizing the impact of urban emissions on regional aerosol particles: airborne measurements during the MEGAPOLI experiment, Atmos. Chem. Phys., 14, 1397-1412, doi:10.5194/acp-14-1397-2014, 2014.

Gaffin, S. R., Rosenzweig, C., Khanbilvardi, R., Parshall, L., Mahani, S., Glickman, H., Goldberg, R., Blake, R., Slosberg, R. B., and Hillel, D.: Variations in New York City's urban heat island strength over time and space, Theor. Appl. Climatol., 94, 1-11, doi:10.1007/s00704-007-0368-3, 2008.

García, O. E., Díaz, J. P., Expósito, F. J., Díaz, A. M., Dubovik, O., Derimian, Y., Dubuisson, P., and Roger, J.-C.: Shortwave radiative forcing and efficiency of key aerosol types using AERONET data, Atmos. Chem. Phys., 12, 5129-5145, doi:10.5194/acp-125129-2012, 2012.

Giorgi, F., Bi, X., and Qian, Y.: Direct radiative forcing and regional climatic effects of anthropogenic aerosols over East Asia: A regional coupled climate-chemistry/aerosol model study, J. Geophys. Res., 107, 4439, doi:10.1029/2001JD001066, 2002. 
Giorgi, F., Coppola, E., Solmon, F., Mariotti, L., Sylla, M., Bi, X., Elguindi, N., Diro, G. T., Nair, V., Giuliani, G., Cozzini, S., Guettler, I., O’Brien, T. A., Tawfi, A. B., Shalaby, A., Zakey, A., Steiner, A., Stordal, F., Sloan, L., and Brankovic, C.: RegCM4: model description and preliminary tests over multiple CORDEX domains, Clim. Res., 52, 7-29, 2012.

Guenther, A. B., Zimmermann, P. C., Harley, R., Monson, R. K., and Fall, R.: Isoprene and monoterpene emission rate variability: model evaluations and sensitivity analyses, J. Geophys. Res., 98, 12609-12617, 1993.

Guttikunda, K. S., Carmichael, G. R., Calori, G., Eck, C., and Woo, J.-H.: The contribution of megacities to regional sulfur pollution in Asia, Atmos. Environ., 37, 11-22, doi:10.1016/S13522310(02)00821-X, 2003.

Grell, G.: Prognostic evaluation of assumptions used by cumulus parameterizations, Mon. Weather Rev., 121, 764-787, 1993.

Grell, G. and Baklanov, A.: Integrated modeling for forecasting weather and air quality: a call for fully coupled approaches, Atmos. Environ., 45, 6845-6851, 2011.

Hodnebrog, Õ., Stordal, F., and Berntsen, T. K.: Does the resolution of megacity emissions impact large scale ozone?, Atmos. Environ., 45, 6852-6862, 2011.

Holtslag, A. A. M., de Bruijn, E. I. F., and Pan, H.-L.: A high resolution air mass transformation model for shortrange weather forecasting, Mon. Weather Rev., 118, 1561-1575, 1990.

Hou, A., Ni, G., Yang, H., and Lei, Z.: Numerical Analysis on the Contribution of Urbanization to Wind Stilling: an Example over the Greater Beijing Metropolitan Area, J. Appl. Meteorol. Clim., 52, 1105-1115, doi:10.1175/JAMC-D-12-013.1, 2013.

Huszar, P., Miksovsky, J., Pisoft, P., Belda, M., and Halenka, T.: Interactive coupling of a regional climate model and a chemistry transport model: evaluation and preliminary results on ozone and aerosol feedback, Clim. Res., 51, 59-88, doi:10.3354/cr01054, 2012

Huszar, P., Teyssédre, H., Michou, M., Voldoire, A., Olivié, D. J. L., Saint-Martin, D., Cariolle, D., Senesi, S., Salas Y Melia, D., Alias, A., Karcher, F., Ricaud, P., and Halenka, T.: Modeling the present and future impact of aviation on climate: an AOGCM approach with online coupled chemistry, Atmos. Chem. Phys., 13, 10027-10048, doi:10.5194/acp-13-10027-2013, 2013.

Huszar, P., Halenka, T., Belda, M., Zak, M., Sindelarova, K., and Miksovsky, J.: Regional climate model assessment of the urban land-surface forcing over central Europe, Atmos. Chem. Phys., 14, 12393-12413, doi:10.5194/acp-14-12393-2014, 2014.

Huszar, P., Belda, M., and Halenka, T.: On the long-term impact of emissions from central European cities on regional air quality, Atmos. Chem. Phys., 16, 1331-1352, doi:10.5194/acp-16-13312016, 2016.

Im, U. and Kanakidou, M.: Impacts of East Mediterranean megacity emissions on air quality, Atmos. Chem. Phys., 12, 6335-6355, doi:10.5194/acp-12-6335-2012, 2012.

Im, U., Poupkou, A., Incecik, S., Markakis, K., Kindap, T., Unal, A., Melas, D., Yenigun, O., Topcu, O., Odman, M. T., Tayanc, M., and Guler, M.: The impact of anthropogenic and biogenic emissions on surface ozone concentrations in Istanbul, Sci. Total Environ., 409, 1255-1265, doi:10.1016/j.scitotenv.2010.12.026, 2011a.

Im, U., Markakis, K., Poupkou, A., Melas, D., Unal, A., Gerasopoulos, E., Daskalakis, N., Kindap, T., and Kanakidou, M.: The im- pact of temperature changes on summer time ozone and its precursors in the Eastern Mediterranean, Atmos. Chem. Phys., 11, 3847-3864, doi:10.5194/acp-11-3847-2011, $2011 \mathrm{~b}$.

Jacob, D., Petersen, J., Eggert, B., Alias, A., Christensen, O. B., Bouwer, L., Braun, A., Colette, A., Déqué, M., Georgievski, G., Georgopoulou, E., Gobiet, A., Menut, L., Nikulin, G., Haensler, A., Hempelmann, N., Jones, C., Keuler, K., Kovats, S., Kröner, N., Kotlarski, S., Kriegsmann, A., Martin, E., Meijgaard, E., Moseley, C., Pfeifer, S., Preuschmann, S., Radermacher, C., Radtke, K., Rechid, D., Rounsevell, M., Samuelsson, P., Somot, S., Soussana, J.-F., Teichmann, C., Valentini, R., Vautard, R., Weber, B., and Yiou, P.: EURO-CORDEX: new high-resolution climate change projections for European impact research Regional Environmental Change, Springer, Berlin, Heidelberg, Germany, 1-16, 2013.

Juda-Rezler, K., Reizer, M., Huszar, P., Krueger, B., Zanis, P., Syrakov, D., Katragkou, E., Trapp, W., Melas, D., Chervenkov, H., Tegoulias, I., and Halenka, T.: Modelling the effects of climate change on air quality over central and Eastern Europe: concept, evaluation and projections, Clim. Res., 53, 179-203, doi:10.3354/cr01072, 2012.

Kanakidou, M., Seinfeld, J. H., Pandis, S. N., Barnes, I., Dentener, F. J., Facchini, M. C., Van Dingenen, R., Ervens, B., Nenes, A., Nielsen, C. J., Swietlicki, E., Putaud, J. P., Balkanski, Y., Fuzzi, S., Horth, J., Moortgat, G. K., Winterhalter, R., Myhre, C. E. L., Tsigaridis, K., Vignati, E., Stephanou, E. G., and Wilson, J.: Organic aerosol and global climate modelling: a review, Atmos. Chem. Phys., 5, 1053-1123, doi:10.5194/acp-5-1053-2005, 2005.

Kanakidou, M., Mihalopoulos, N., Kindap, T., Im, U., Vrekoussis, M., Gerasopoulos, E., Dermitzaki, E., Unal, A., Kocak, M., Markakis, K., Melas, D., Kouvarakis, G., Youssef, A. F., Richter, A., Hatzianastassiou, N., Hilboll, A., Ebojie, F., von Savigny, C., Ladstaetter-Weissenmayer, A., Burrows, J., and Moubasher, H.: Megacities as hot spots of air pollution in the East Mediterranean, Atmos. Environ., 45, 1223-1235, 2011.

Kasoar, M., Voulgarakis, A., Lamarque, J.-F., Shindell, D. T., Bellouin, N., Collins, W. J., Faluvegi, G., and Tsigaridis, K.: Regional and global temperature response to anthropogenic $\mathrm{SO}_{2}$ emissions from China in three climate models, Atmos. Chem. Phys., 16, 9785-9804, doi:10.5194/acp-16-9785-2016, 2016.

Kastner-Klein, P., Fedorovich, E., and Rotach, M. W.: A wind tunnel study of organised and turbulent air motions in urban street canyons, J. Wind Eng. Ind. Aerod., 89, 849-861, 2001.

Kiehl, J., Hack, J., Bonan, G., Boville, B., Breigleb, B., Williamson, D., and Rasch, P.: Description of the NCAR Community Climate Model (CCM3), National Center for Atmospheric Research Tech Note NCAR/TN-420+STR, NCAR, Boulder, CO, USA, 1996.

Kiehl, J. T., Schneider, T. L., Rasch, P. J., Barth, M. C., and Wong, J.: Radiative forcing due to sulfate aerosols from simulations with the National Center for Atmospheric Research Community Climate Model Version 3, J. Geophys. Res., 105, 1441-1457, 2000.

Kotlarski, S., Keuler, K., Christensen, O. B., Colette, A., Déqué, M., Gobiet, A., Goergen, K., Jacob, D., Lüthi, D., van Meijgaard, E., Nikulin, G., Schär, C., Teichmann, C., Vautard, R., Warrach-Sagi, K., and Wulfmeyer, V.: Regional climate modeling on European scales: a joint standard evaluation of the EURO- 
CORDEX RCM ensemble, Geosci. Model Dev., 7, 1297-1333, doi:10.5194/gmd-7-1297-2014, 2014.

Kuenen, J., Denier van der Gon, H., Visschedijk, A., van der Brugh, H., Finardi, S., Radice, P., d'Allura, A., Beevers, S., Theloke, J., Uzbasich, M., Honor, C., and Perrussel, O.: A Base Year (2005) MEGAPOLI European Gridded Emission Inventory (Final Version), Deliverable D1.6, MEGAPOLI Scientific Report 10-17, MEGAPOLI-20-REP-2010-10, TNO Built Environment and Geosciences, Utrecht, the Netherlands, p. 39, 2010.

Kuhn, U., Ganzeveld, L., Thielmann, A., Dindorf, T., Schebeske, G., Welling, M., Sciare, J., Roberts, G., Meixner, F. X., Kesselmeier, J., Lelieveld, J., Kolle, O., Ciccioli, P., Lloyd, J., Trentmann, J., Artaxo, P., and Andreae, M. O.: Impact of Manaus City on the Amazon Green Ocean atmosphere: ozone production, precursor sensitivity and aerosol load, Atmos. Chem. Phys., 10, 9251-9282, doi:10.5194/acp-10-9251-2010, 2010.

Lawrence, M. G., Butler, T. M., Steinkamp, J., Gurjar, B. R., and Lelieveld, J.: Regional pollution potentials of megacities and other major population centers, Atmos. Chem. Phys., 7, 39693987, doi:10.5194/acp-7-3969-2007, 2007.

Lee, S.-H., Kim, S.-W., Angevine, W. M., Bianco, L., McKeen, S. A., Senff, C. J., Trainer, M., Tucker, S. C., and Zamora, R. J.: Evaluation of urban surface parameterizations in the WRF model using measurements during the Texas Air Quality Study 2006 field campaign, Atmos. Chem. Phys., 11, 2127-2143, doi:10.5194/acp-11-2127-2011, 2011.

Li, G., Zavala, M., Lei, W., Tsimpidi, A. P., Karydis, V. A., Pandis, S. N., Canagaratna, M. R., and Molina, L. T.: Simulations of organic aerosol concentrations in Mexico City using the WRFCHEM model during the MCMA-2006/MILAGRO campaign, Atmos. Chem. Phys., 11, 3789-3809, doi:10.5194/acp-11-37892011, 2011.

Liggio, J., Li, S. M., Vlasenko, A., Sjostedt, S., Chang, R., Shantz, N., Abbatt, J., Slowik, J. G., Bottenheim, J. W., Brickell, P. C., Stroud, C., and Leaitch, W. R.: Primary and secondary organic aerosols in urban air masses intercepted at a rural site, J. Geophys. Res.-Atmos., 115, D21305, doi:10.1029/2010JD014426, 2010.

Liou, K. N.: An Introduction to Atmospheric Radiation, Academic Press, San Diego, CA, USA, 2002.

Markakis, K., Valari, M., Perrussel, O., Sanchez, O., and Honore, C.: Climate-forced air-quality modeling at the urban scale: sensitivity to model resolution, emissions and meteorology, Atmos. Chem. Phys., 15, 7703-7723, doi:10.5194/acp-15-7703-2015, 2015.

Markakis, K., Valari, M., Engardt, M., Lacressonniere, G., Vautard, R., and Andersson, C.: Mid-21st century air quality at the urban scale under the influence of changed climate and emissions case studies for Paris and Stockholm, Atmos. Chem. Phys., 16, 1877-1894, doi:10.5194/acp-16-1877-2016, 2016.

McMeeking, G. R., Kreidenweis, S. M., Carrico, C., Lee, T., Collett Jr., J. L., and Malm, W. C.: Observations of smoke-influenced aerosol during the Yosemite Aerosol Characterization Study: size distributions and chemical composition, J. Geophys. Res., 110, D09206, doi:10.1029/2004JD005389, 2005.

Molina, L. T., Madronich, S., Gaffney, J. S., Apel, E., de Foy, B., Fast, J., Ferrare, R., Herndon, S., Jimenez, J. L., Lamb, B., Osornio-Vargas, A. R., Russell, P., Schauer, J. J., Stevens, P. S., Volkamer, R., and Zavala, M.: An overview of the MILA-
GRO 2006 Campaign: Mexico City emissions and their transport and transformation, Atmos. Chem. Phys., 10, 8697-8760, doi:10.5194/acp-10-8697-2010, 2010.

Nenes, A., Pandis, S. N., and Pilinis, C.: ISORROPIA: a new thermodynamic equilibrium model for multiphase multicomponent inorganic aerosols, Aquat. Geochem., 4, 123-152, 1998.

Nguimdo, L. A. and Njomo, D.: Shortwave Cloud and Aerosol Radiative Forcings and Their Effects on the Vertical Local Heating/Cooling Rates, Atmos. Clim. Sci., 03, 337-347, doi:10.4236/acs.2013.33035, 2013.

Oke, T. R.: The energetic basis of the urban heat island, Q. J. Roy. Meteor. Soc., 108, 1-24, doi:10.1002/qj.49710845502, 1982.

Olivié, D. J. L., Cariolle, D., Teyssèdre, H., Salas, D., Voldoire, A., Clark, H., Saint-Martin, D., Michou, M., Karcher, F., Balkanski, Y., Gauss, M., Dessens, O., Koffi, B., and Sausen, R.: Modeling the climate impact of road transport, maritime shipping and aviation over the period 1860-2100 with an AOGCM, Atmos. Chem. Phys., 12, 1449-1480, doi:10.5194/acp-12-1449-2012, 2012.

Pal, J. S., Small, E. E., and Eltahir, E. A. B.: Simulation of regional scale water and energy budgets: representation of subgrid cloud and precipitation processes within RegCM, J. Geophys. Res.Atmos., 105, 29579-29594, 2000.

Park, R. J., Stenchikov, G. L., Pickering, K. E., Dickerson, R. R., Allen, D. J., and Kondragunta, S.: Regional air pollution and its radiative forcing: Studies with a single-column chemical and radiation transport model, J. Geophys. Res., 106, 28751-28770, doi:10.1029/2001JD001182, 2001.

Petty, G. W.: A First Course in Atmospheric Radiation (2nd Ed.), Sundog Publishing, Madison, Wisconsin, USA, 2006.

Ramachandran, S. and Kedia, S.: Black carbon aerosols over an urban region: Radiative forcing and climate impact, J. Geophys. Res., 115, D10202, doi:10.1029/2009JD013560, 2010.

RegCM: RegCM4.2 model, available at: http://gforge.ictp.it/gf/ project/regcm/frs, last access: 18 October 2016.

Reid, J. S., Eck, T. F., Christopher, S. A., Koppmann, R., Dubovik, O., Eleuterio, D. P., Holben, B. N., Reid, E. A., and Zhang, J.: A review of biomass burning emissions part III: intensive optical properties of biomass burning particles, Atmos. Chem. Phys., 5, 827-849, doi:10.5194/acp-5-827-2005, 2005.

Richards, K.: Observation and simulation of dew in rural and urban environments, Prog. Phys. Geog., 28, 76-94, 2004.

Roeckner, E., Bengtsson, L., Feichter, J., Lelievelds, J., and Rodhe, H.: Transient climate change simulations with a coupled atmosphere-ocean GCM including the tropospheric sulfur cycl, J. Clim., 12, 3004-3032, 1999.

Roldin, P., Swietlicki, E., Massling, A., Kristensson, A., Löndahl, J., Eriksson, A., Pagels, J., and Gustafsson, S.: Aerosol ageing in an urban plume - implication for climate, Atmos. Chem. Phys., 11, 5897-5915, doi:10.5194/acp-11-5897-2011, 2011.

Roth, M.: Review of atmospheric turbulence over cities, Q. J. Roy. Meteor. Soc., 126, 941-990, 2000.

Rozoff, C. M., Cotton, W. R., and Adegoke, J. O.: Simulation of St. Louis, Missouri, land use impacts on thunderstorms, J. Appl. Meteorol., 42, 716-738, 2003.

Schaap, M., van Loon, M., ten Brink, H. M., Dentener, F. J., and Builtjes, P. J. H.: Secondary inorganic aerosol simulations for Europe with special attention to nitrate, Atmos. Chem. Phys., 4, 857-874, doi:10.5194/acp-4-857-2004, 2004. 
Seinfeld, J. H. and Pandis, S. N.: Atmospheric Chemistry and Physics: From Air Pollution to Climate Change, J. Wiley, New York, USA, 1998.

Simmons, A. J., Willett, K. M., Jones, P. D., Thorne, P. W., and Dee, D. P.: Low-frequency variations in surface atmospheric humidity, temperature and precipitation: inferences from reanalyses and monthly gridded observational datasets, J. Geophys. Res., 115, D01110, doi:10.1029/2009JD012442, 2010.

Skyllakou, K., Murphy, B. N., Megaritis, A. G., Fountoukis, C., and Pandis, S. N.: Contributions of local and regional sources to fine PM in the megacity of Paris, Atmos. Chem. Phys., 14, 23432352, doi:10.5194/acp-14-2343-2014, 2014.

Stock, Z. S., Russo, M. R., Butler, T. M., Archibald, A. T., Lawrence, M. G., Telford, P. J., Abraham, N. L., and Pyle, J. A.: Modelling the impact of megacities on local, regional and global tropospheric ozone and the deposition of nitrogen species, Atmos. Chem. Phys., 13, 12215-12231, doi:10.5194/acp-1312215-2013, 2013.

Struzewska, J. and Kaminski, J. W.: Impact of urban parameterization on high resolution air quality forecast with the GEM - AQ model, Atmos. Chem. Phys., 12, 10387-10404, doi:10.5194/acp12-10387-2012, 2012.

Theloke J., Blesl, M., Bruchhof, D., Kampffmeyer, T., Kugler, J., Uzbasich, M., Schenk, K., Denier van der Gon, H., Finardi, S., Radice, P., Sokhi, R. S., Ravindra, K., Beevers, S., Grimmond, S., Coll, I., Friedrich, R., and van den Hout, D.: European and megacity baseline scenarios for 2020, 2030 and 2050. Deliverable D1.3, MEGAPOLI Scientific Report 10-23, MEGAPOLI-26-REP-2010-12, 57p, TNO Built Environment and Geosciences, Utrecht, the Netherlands, 2010.

Tie, X., Geng, F., Guenther, A., Cao, J., Greenberg, J., Zhang, R., Apel, E., Li, G., Weinheimer, A., Chen, J., and Cai, C.: Megacity impacts on regional ozone formation: observations and WRFChem modeling for the MIRAGE-Shanghai field campaign, Atmos. Chem. Phys., 13, 5655-5669, doi:10.5194/acp-13-56552013, 2013.

Timothy, M. and Lawrence, M. G.: The influence of megacities on global atmospheric chemistry: a modeling study, Environ. Chem., 6, 219-225, doi:10.1071/EN08110, 2009.

Torma, C., Bartholy, J., Pongracz, R., Barcza, Z., Coppola, E., and Giorgi, F.: Adaptation and validation of the RegCM3 climate model for the Carpathian Basin, IDOJARAS - Q. J. Hung. Meteorol. Serv., 112, 233-247, 2008.

Torma, C., Coppola, E., Giorgi, F., Bartholy, J., and Pongrácz, R: Validation of a High-Resolution Version of the Regional Climate Model RegCM3 over the Carpathian Basin, J. Hydrometeorol., 12, 84-100, 2011.

Tripathi, S. N., Dey, S., Tare, V., and Satheesh, S. K.: Aerosol black carbon radiative forcing at an industrial city in northern India, Geophys. Res. Lett., 32, L08802, doi:10.1029/2005GL022515, 2005.

Trusilova, K., Jung, M., Churkina, G., Karstens, U., Heimann, M. and Claussen, M.: Urbanization Impacts on the Climate in Europe: Numerical Experiments by the PSU-NCAR Mesoscale Model (MM5), J. Appl. Meteor. Climatol., 47, 1442-1455, doi:10.1175/2007JAMC1624.1, 2008

United Nations: Population Division of the Department of Economic and Social Affairs of the United Nations Secretariat, World Population Prospects: The 2008 Revision and World
Urbanization Prospects: The 2009 Revision, https://esa.un.org/ unpd/wpp/Publications/, New York, USA, 2009.

van den Besselaar, E. J. M., Haylock, M. R., van der Schrier, G., and Klein Tank, A. M. G.: A European Daily High-resolution Observational Gridded Data set of Sea Level Pressure, J. Geophys. Res., 116, D11110, doi:10.1029/2010JD015468, 2011.

Wang, J., Feng, J., Yan, Z., Hu, Y., and Jia, G.: Nested highresolution modeling of the impact of urbanization on regional climate in three vast urban agglomerations in China, J. Geophys. Res., 117, D21103, doi:10.1029/2012JD018226, 2012.

Wang, T., Li, S., Shen, Y., Deng, J., and Xie, M.: Investigations on direct and indirect effect of nitrate on temperature and precipitation in China using a regional climate chemistry modeling system, J. Geophys. Res., 115, D00K26, doi:10.1029/2009JD013264, 2010.

Wang, Y., Zhang, Q. Q., He, K., Zhang, Q., and Chai, L.: Sulfatenitrate-ammonium aerosols over China: response to 2000-2015 emission changes of sulfur dioxide, nitrogen oxides, and ammonia, Atmos. Chem. Phys., 13, 2635-2652, doi:10.5194/acp-132635-2013, 2013.

Wang, X., Yang, M. and Pang, G.: Influences of Two Land-Surface Schemes on RegCM4 Precipitation Simulations over the Tibetan Plateau, Adv. Meteorol., 2015, 106891, doi:10.1155/2015/106891, 2015.

Winiwarter, W. and Zueger, J.: Pannonisches Ozonprojekt, Teilprojekt Emissionen, Endbericht, Report OEFZS-A-3817, Austrian Research Center, Seibersdorf, Austria, 1996.

Winter, J. M., Pal, J. S., and Eltahir, E. A. B.: Coupling of Integrated Biosphere Simulator to Regional Climate Model version 3, J. Climate, 22, 2743-2757, 2009.

Wouters, H., De Ridder, K., Demuzere, M., Lauwaet, D., and van Lipzig, N. P. M.: The diurnal evolution of the urban heat island of Paris: a model-based case study during Summer 2006, Atmos. Chem. Phys., 13, 8525-8541, doi:10.5194/acp-13-85252013, 2013.

Yarwood. G., Rao, S., Yocke, M., and Whitten, G. Z.: Updates to the Carbon Bond chemical mechanism: CB05, Final Report prepared for US EPA, http://www.camx.com/publ/pdfs/CB05_ Final_Report_120805.pdf, Novato, NC, USA, 2005.

Yu, H., Liu, S. C., and Dickinson, R.: Radiative effects of aerosols on the evolution of the evolution of the atmospheric boundary layer, J. Geophys. Res., 107, 4142, doi:10.1029/2001JD000754, 2002.

Zanis, P.: A study on the direct effect of anthropogenic aerosols on near surface air temperature over Southeastern Europe during summer 2000 based on regional climate modeling, Ann. Geophys., 27, 3977-3988, doi:10.5194/angeo-27-3977-2009, 2009.

Zanis, P., Ntogras, C., Zakey, A., Pytharoulis, I., and Karacostas, T.: Regional climate feedback of anthropogenic aerosols over Europe with RegCM3, Clim. Res., 52, 267-278, doi:10.3354/cr01070, 2012.

Zanis, P., Katragkou, E., Ntogras, C., Marougianni, G., Tsikerdekis, A., Feidas, H., Anadranistakis, E., and Melas, D.: Transient highresolution regional climate simulation for Greece over the period 1960-2100: evaluation and future projections, Clim. Res., 64, 123-140, 2015. 